University of Louisville

ThinkIR: The University of Louisville's Institutional Repository

1931

\title{
The effect of potassium-iodide on the embryological development of the chick with special reference to the growth of the long bones.
}

David M. Polot 1904-1978

University of Louisville

Follow this and additional works at: https://ir.library.louisville.edu/etd

Part of the Biology Commons, Developmental Biology Commons, and the Poultry or Avian Science Commons

\section{Recommended Citation}

Polot, David M. 1904-1978, "The effect of potassium-iodide on the embryological development of the chick with special reference to the growth of the long bones." (1931). Electronic Theses and Dissertations. Paper 1854.

https://doi.org/10.18297/etd/1854

This Master's Thesis is brought to you for free and open access by ThinkIR: The University of Louisville's Institutional Repository. It has been accepted for inclusion in Electronic Theses and Dissertations by an authorized administrator of ThinkIR: The University of Louisville's Institutional Repository. This title appears here courtesy of the author, who has retained all other copyrights. For more information, please contact thinkir@louisville.edu. 


\title{
UNIVERSITY OF IOUISVIILE
}

THE EFFECT OF POTASSIUM-IODIDE ON THE EMBRYOLOGICAL DEVELOPMENT OF THE CHICR;

WITH SPECIAL REFERENCE TO THE GROWTH

OF THE LONG BONES

\author{
A Dissertation \\ Subritted to the Faculty \\ of the Graduate School of the University of Louf avilie \\ In Partial Fulfillment of the \\ Requirements for the Degree \\ of Master of Science
}

Department of $\mathrm{Blology}$

By

David M. Polot 
My deep gratitude is due Dr. Austin R. Middleton, Director of the Biological Laboratories of the University of Loulgvilie, for his gracious guidance and constructive criticism of the work. 
CONTENTS

1. Historical.........................

2. Materials and Technique.................

3. Results...........................16

4. Discussion........................46

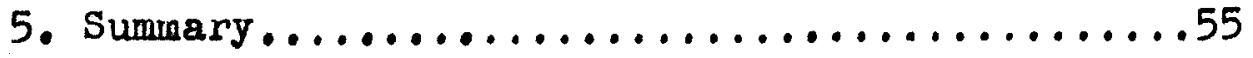

6. Blbliography .......................58 
HISTORI CAL 
Since 1820 lodine has been used more or less in the treatment of thyroid dieeases, but it was not unt1l 1895 that it became known that the gland usually containg iodine.

Baumann ('95)' discovered that lodine was a constituent of the normal thyroid gland. By treating the glands of sheep with a strong acia he was able to destroy most of the complex materials present and to seperate a.mixture of substances which containsabout nine per cent lodine. This work was closely follow by an investigation of the lodine content of normal and diseased thyrold glands and it became evident that the activity of the thyroid was closely related to the amount of lodine the gland contained. It has been shown in a number of papers that the administration of lodine, in the inorganic and organic form, produced a marked effet upon the normal physiological development. This effect may result in a change of normal body metaboligm or body growth, and when this abnormality occurs, it is called hyperthyroidism.

Terry $(18)^{2}$ found that the removal of the thjold gland greatly retarded, if $\mathrm{n}^{\circ}$; completely stopped the process of ossification and the process of growth in the bones of the hind legs of Rana pipiens.

Hofmeister $(96)^{3}$ showed that the extirpation of the 
thyrold of young rabbits, was followed by a remarkable retardation of the long bones, to the extent of at least a third of their proper length. "The most constant symptom," says.V. Bruins, "In man as well as in animals is a remarkable disturbance of growth. The arrest of development produces a dwarf-like appearance of the individual due to improper endochondral ossification." Allen('18) 4 states: "It 1s thus clear that both hind limbs and fore limbs can atart to develop in the total absence of the thyrold gland of Rana pipiens, but their development ceases at an early stage. In case of the hind legs, this is readily seen."

Swingle('19) shows that lodine and 1 ts compounds when fed to the larvae of Rasa njpieng and Bufo lentiginosus stimulate metamorphosis in these animals. Inorganic lodine when fed to the thyrolaless larvae of Bufo lentiginosus brings about metamorphosis in an abnormally short time.

Iodine appears to function within the organism as a hormone itself without the intermediation of the gland. Swingle suggests that the extraction of lodine from the blood and its storage is the chlef function of the thyrold gland. In this connection he also mentions tests made to determine the solubility of lodine in normal blood serums in amphibia and mammals (rats). The serum of the latter at thirty-seven degrees Centigrade acts as a *Quoted From Bledle; Internal secretory organs. 
solvent for finely ground lodine crystals to the extent of 0.00075 gram per cubic centimeter when stirred vigonously.

Kendall('15) has reported that the relation of lodine to the physlological activity of the thyroid is very close; in fact, the activity of the gland appears tp depend upon its lodine content. Lenhart('15) 7 fed thyroid tisaue to tadpoles and observed that the higher the lodine content of the gland fed, the more rapid the body metabolism.

Swingle('19) 8 in comparing the thyrold gland of lodine fed and normal fros larvae, showed that the follicles of the glands of such lodine fed larvae contain a much greater collold mass than the follicles of the controls. He also showed that the solutions of lodine brought about metamorphosis in both normal and thyroldiess tadpoles in a short time. Iodine was much more active in accelerating metamorphosis than any of 1ts compounds. Next in the order of activity were lodoform and potassium-lodide. The lodates of potassium, he claimed, appeared to have no effect.

Dye and Maughan('20)9 deduced from their analysis that in thyroidectomy there is a noticeable retardation of growth with a more or less marked deposit of adpose tissue, and that in the modification of growth in the bones their length was mainly affected. Etkin( 30$)^{10}$ in his work on the growth of the thyroid 
gland, showed a relationship between the physiological activity of the gland and the growth of the hind limbs of Rana pipiens during the stages of metamorphosis. He states that, "The amount of thyroid(cell number or colloid volume) per unit volume of tissue increases but slightly if at all until the hind legs start growing actively." Cretinism and myxedema have been produced experimentaliy In owine by Cayror and Schlotthauer('26) ${ }^{11}$.

Landauer('29) 12 observed thyrogenous dwarfism(myxedema infantiles) in the domestic fowl, whoch he attributes to a hyperth-groid gland.

Speldel('29) ${ }^{13}$ has shown that the regeneration of the amputated tall of a thyroid treated amphibian larvae was hindered by the thyrold hormone, especially if the thyrold treatment was begun before regenerative process was well established. If the thyrold treatment was administered moce than two days before the operation no regeneration took place, although there was some tall regulaion. The removal of the thyrold gland(Allen 18) 4 affects in no way the earlier phases of development, but at a certain definite stage, further development of the some is dependant upon 1 ts presence. Thyroid administration to thyroidless tadpoles brought abour a resumption of development even four months after it had ceased. Hanan('28) ${ }^{14}$ ruduced an abnormal physiological condition in tise hen's egs by the introduction into the 
a1r sack of $1 / 49,000 \mathrm{mg}$. of thyroxin, at the eight day of incubation, and produced an increase of $\mathrm{CO}_{2}$ extending through the following three days. This was followed by a perlod of depresilon below normal, lasting elght days. Sheard and Higgins'('30) 15 investigation have shown that treadiation with an alr-cooled quartz-mercury are tends to increse the rate of metabolism. By removing part of the eg8 shell and replacing the removed shell with a cover glas they firmly established the fact that incubated egss can be oporated upon to produce definite results.

willier ('24) 15 grafted thyrold upon the vascular chorio-allanto1c membrane of the developing chick embryo for the purpose of analyzing the function of the thyroid gland in the development of the chick.

The results he records are: that the best thyrold grafts produce the following typlcal modifications in the host embryo. (1) The body was quite emaciated and considerably smaller than the control, one third smallei in some cases. (2) Shortening and emaciation of the segments of the wings and particularly of the legs occured.(3) The amount of fati stored was less than in controls.

He regards such modifications as reduction in stze and emaciation of the body as hyperthyrold symptoms. These conditions he interprets to mean that metabolism was increased; more particularly there was an acceleration of 
catabolism over anabolism. Fillier also noted in his comparison of the results of hyperthyrold activity in the chlck and frog embryos that:

(1) Hyperthyroid symptoms occur in both.

(2) There is a striking difference in the Irog when metamorphisis is induced, while this change does not occur in the chick. Many investigations have also shown that there is a definte relationship between the amount of lodine and the histological structure of the thyroid.

In his experiment on the hyperplastic glands of oppossum, Bensley $(' 16)^{17}$ found that, as was true of Swingle's tadpole, follicular collold was somewhat increased when lodine was administered dally to these animals.

In the microscopic examination of the collold content of the glands of the two experimentals and two control cultures of frog larvae, Swingle $(19)^{8}$ showed a marked difference in the amount of collold visible in the follicle. The glands of the lodine-fed animals were packed with this substance, whereas the gland of the cortinl showed a rather scanty amount.

Gray and Rabinovitch ('29) ${ }^{18}$ have shown that the thyrold gland of the guinea pig is atimulated in all its histological phases when $0.01 \mathrm{gm}$. of potassium-iodide was fed datly. Marine and Lenhart $(' 09)^{19}$ made a study of the effect 
of the administration of lodine upon many different animals. They found that in such lodine treated animals the thyroid contained more colloid than in the normal glands of the controls. Yet, Claude and Blauchetiere ('10)20 state that the lodine content and the amount of collold are not belated to each other, and that all degrees of disproportion exist. There may be much collold and no lodine, or much lodine and no demonstrable collo1d. Uhlenhuth ('22) 21 has shown that in a hyperactive thyroid gland intracellular vacuoles migrate toward the lumen and seem to be thrust into the follicle by a process of constriction. Thes can be seen in the acini of the epethilial lining and are markedly increased in amount in the hyperactive gland.

According to key ('25) 22 the non-staining vacuole-like bodies are not really vacuoles, but represent areas of greater fluidity in the dense colloid. These vacuoles contain the active secretion of the thyroid gland and may serve as a histological criterion of the degree of activity of the gland.

There are many different theories and conflicting opinions concerning the role the thyrold gland plays In the physiology of the body, but all investigators agree that lodine or some lodine containing compound is essential for physiologieal and histological changes 
that occur in the animal body and in the thyrold gland. So It seems just to conclude that the arrest of growth of the skeletal organs is a typical and invariable result of abnormal thyroid function.

The present study was undertaken in the hope of securing further data which might throw more light upon the effect of lodine on the thyroid in relation to the growth of the long bones of the chick embryo, by placing potassiumlodide crystals on the egs shell membrane.

The questions with which the present investigation deals are:

(1) Can potassium-iodide produce the same effect in chick embryos as the hormone of the thyroid grafts in the chick embryo and in the larvae of Rana pipiens and Bufo lentiginosus (Swingle '19)5q (2) Is there any relation between the histological structures of a hyperactive gland and the growth of the long bones? 
MATERIALS AND TECHNIQUE 
Eggs from various breeds of chlckens were obtained for this experiment, although eggs of the same breed were used for each series. Special care was taken to select eggs of approximately the same size. White leghorns and Rhode Island Reds rere chiefly used as they wo'e easily obtainable in this region. It impossible to obtain a good batch of fertile eggs in the late fall. However, fifty eggs were 1ncubated on November 2, 1930, of wh1ch only four egge showed signs of fertility.

The first series of good fertile eggs was incubated of February 9, 1931.

A "Lectro-hatch" type of incubator w1 th a thermostatic control and holding approximately fifty eggs was used. Care was taken in controlling the incubator so that a constant temperature 39 degrees Centigrade and proper molature were maintained. The eggo were not disturbed during the first three days of incubation, but there after they were turned daily. On the third day each egs was candled over a seventy-five watt electric light in order to eliminate those eggs which showed no sign of fertility. (Waite ' 28$)^{23}$

on the tenth day each egg was again candled, and the area of the shell showing the greatest caplilary network was marized with a pencil on the egs shell. Each egs was weighed, and the weight recorded on the 
eg8 shell. They were then arranged in a series so that each experimental egg weighed approximately the same as the control eggs, for it has been found that there is quite a consistent relation between the weight of eg8 used for hatching and the welght and size of the chick at hatching time. (Halbersleben and Mussehl '22) ${ }^{24}$ one egg at a time was removed from the incubator on the eleventh day of incubation to be prepared for the introduction of the potassium-1odide crystals. The egg was placed on a pad of cotton, with the marked surface facing upward and With some absorbent cotton molstened in distilled water the marked area was washed clean and then sterilized with cotton molstened in elghty-five per cent. alcohol.

A fine coping saw that had been carefully sterilized by heating in an open flame and submerged in elghtyfive per cent. alcohol was used to cut out a rectangular piece of the shell in the region of the marked area. Great care was taken to araid sawing too deep for fear of breaking the underlying vascular membrane. Bleeding occurs when the allantolc membrane is torn.

With a sterilized forceps, a crystal of potassiumlodide(U.S.P.), welghing not more than 9.05 gram or less than 0.01 gram, was introduced on the egs shell membrane (Danchakofe 17)25. The rectangular window was then replaced and sealed in place by applying melted parafine in the grooves with a hot sterillzed scalpel. The egs 
was returned to the incubator with the operated surface up.* Tindows were also cut in fifty per cent. of the control expe in each series while the remainirg control eggs were permitted to hatch normally. (F1g. 1 and 2)

Several other methods to introduce potassium-bdide in the eggs were attempted. They were as follows:

\section{Series I}

A solution of one per cent. potassium-1odide was introduced into the egs by dropping 0.1 cubic centimeter of the solution on the egg shell membrane by means of a ten cubic centimeter plpette. One egs ras used at a time to prevent chilling. The egs was returned to the incubator with 1 ta open surface upward and allowed to remain in that position for approximately fifteen minutes in order to allow the solution to be absorbed through the membrane. Fach ege was removed from the incubator, the window replaced and sealed th a strip of adhesive tape large enoughto cover the groove. This method was continued each day until the twentieth day of incubation. This method proved unsatiafactory, because the adhesive tape broke the egg shell when it was removed each day for the introduction of the potassium-iodide solution. However, the experiment was carried through with the esgs that withstood the practice.

* The method as decribed above was worked out in part by Willier('24)16 


\section{Series II}

In this experiment we decided to use the potassiumlodide crystal method; by placing a crystal of potasaiumlodide on the shell membrane and replacing and sealing the window in place with paraffine. This method was found more satisfactory.

\section{Series III}

In this experiment an attempt was made to pierce the shell membrane and introduce the potassium-iodide crystal on the vascular chorio-allantolc membrane. Only five eggs from a group of fitty were used for this method. The potaralum-iodide crystals immediately dissolved and went into solution within the blood in the capillaries. This method, however, proved fatal to the embryos. An attempt was also made to inject one cubic centimeter of one per cent. potassium-iodide solution through the shell membrane by means of a hypodermic needle. This method also proved fatal. The remaining eggs of this series were subjected to the same method used in Series II.

\section{Serieg IV}

A group of twelve, three day old chicka were experimented with by feeding one cubic centimeter of a one per cent. potassium-lodide solution dally for thirteen days in order to determine the histological effect of the potassium-iodide on their thyroid glands. Six chicks were subjected to the treatment while six were 
used for controls.

The solution was administered orally with a one cubic centimeterpipette. Both the experimental and control chicks were raised under the same laboratory condiditons. 


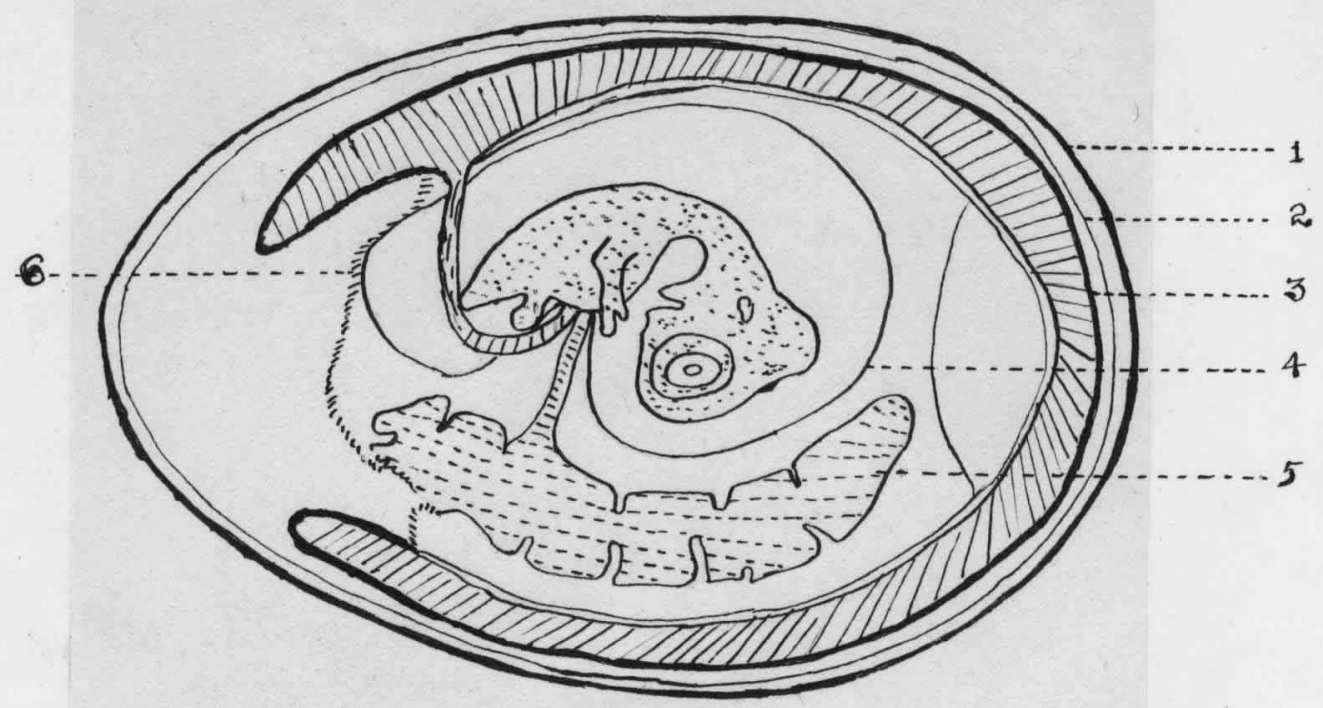

Fig. 1

Diagram of a ten day old chick embryo showing relationship of the important membranes(after Lillie).

1. Egs shell; 2. egg shell membrane; 3.allanto1c membrane (highly vascular); 4.amnionic membrane; 5.yolk sac; 6. chorionic membrane.

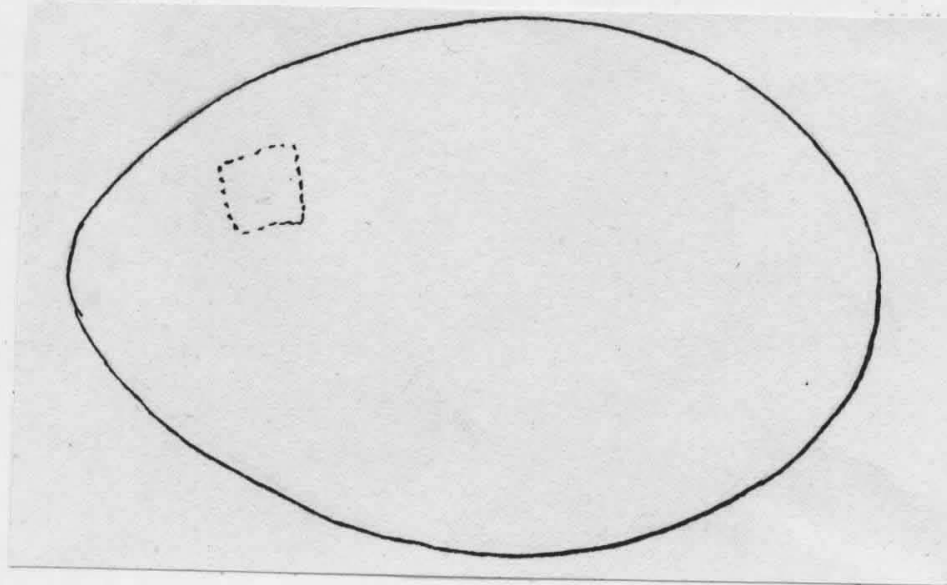

Fig. 2.

Egg, showing position where window was removed. 
RESULTS 
The results of this woric are based upon the study of twenty-six experimental and forty one control chick embryos.

Potassium-iodide was used, because the lodide of potassium has been found to be one of the most diffurable Inorganic substances(Barthalow 03$)^{26}$. It passes into the blood with great rapidity. In the blood, the lodide of potassium becomes an lodide of sodium, and undergoes no further change, and so far as it is known it does not modify the composition of the blood. The diffusion of potassium-iodide into and out of the blood takes place with such rapidity that in fifteen minutes in may be detected in the saliva and urine of human beings.

When the potassium-1odide was placed upon the eggshell membrane in the area of the vascular chorioallantolc membrane, by gradual diffusion it passed through the shell membrane into the vitelline blood vessels or the chorio-allantolc membrane.

By a study of a series of allantoises of the chicks between the sixth and twenty-first day of incubation, Danchakoff $(17)^{25}$ has shom that at the beginning of their development all the vessels are subept thellal; soon, however, a rich caplilary net grows and develops inside of the eplthelium and expand ereely above the surface of the ectoderm immediately under the egg-shell 
membrane. At the thirteenth to fifteenth day of incubation the capillary net is situated above the ectoderm. The meshes in earlier stages surrounded by ectodermal epithelial cells first come at least by one of their surfaces, into immediate contact with the egg-shell membrane. The capillary net situated immediately under the eg8-shell membrane is connected with numerous vessels in the deeper mesodermal layers of the allanto1s. The capillary net actually traversea the ectodermal membrane and expands above it in the form of a rich plexus.

\section{Experiment Series I}

only twenty-eight of the fifty incubated eggs showed signs of fertility of the tenth day. The remaining eggs were rejected.

Seven experimental and twelve control embryos were alive when removed from the shells on the trentieth day of incubation. Five of the experimental embryos, treated with potassium-iodide solution, showed typical signs of retarded growth, as seen in Figure 3 .

Their legs and wings were disarticulated from the pelvic and pectora. 31 rdles and prepared for study by the potasli method(Lee ' 28$)^{27}$.

The bones of the legs and wings become visible and are held intact by the transparent tisgue when prepared by the potash method. The legs and wings were then 
pinned in position on a board and extended horizontal to a centimeter ruler and measured. The leg measurements were taken from the proximal tip of the femur to the distal tip of the third digit, while the wing measurements were taken from the proximal tip of the humerus to the distal tip of the third digit.(Fig. 4) 


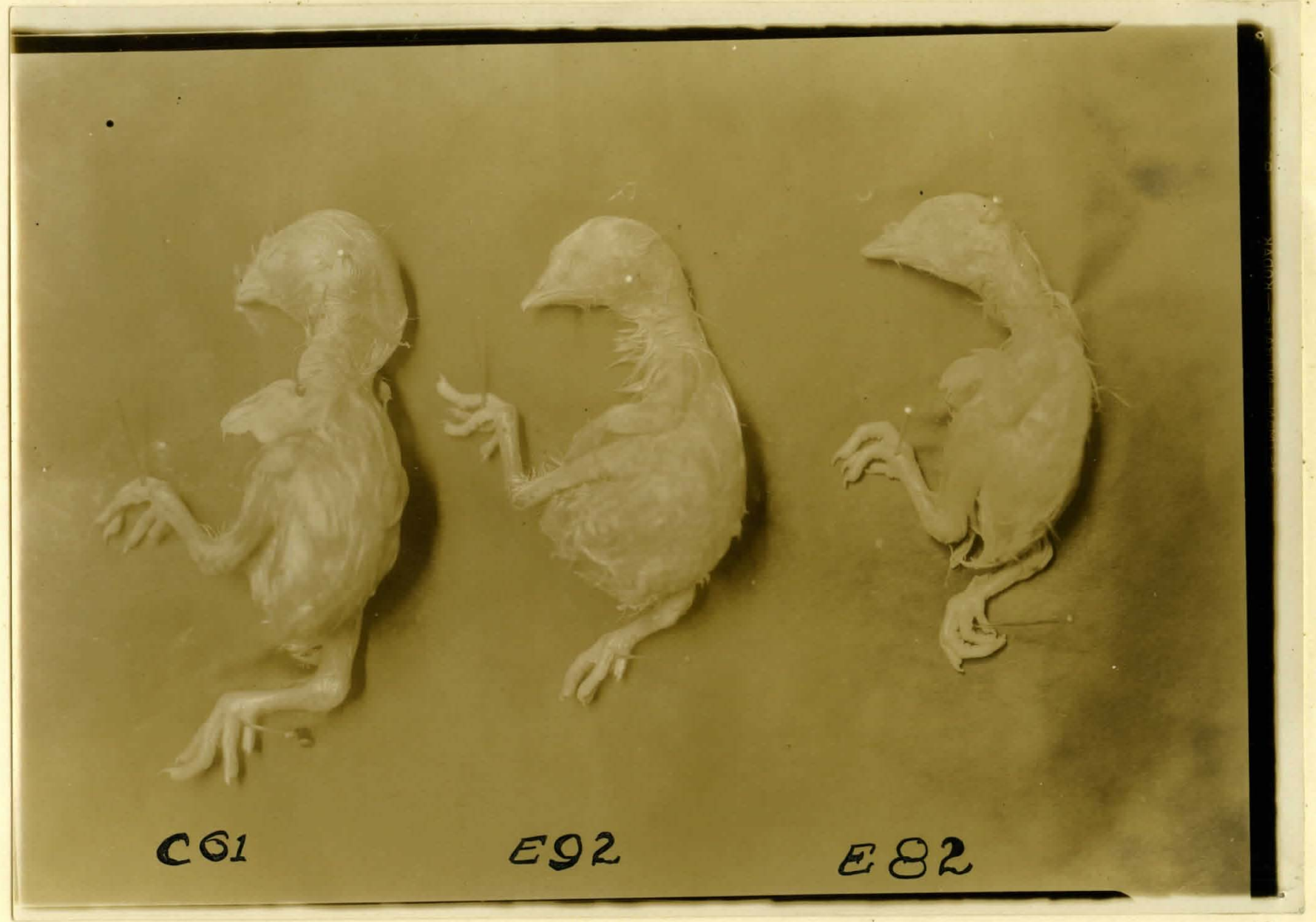

Fig. 3. Comparison of KI-modified chick embryos, E 92 and I 82 with a control embryo, C61. C61 embryo is the control embryo for embryo E 82 . 

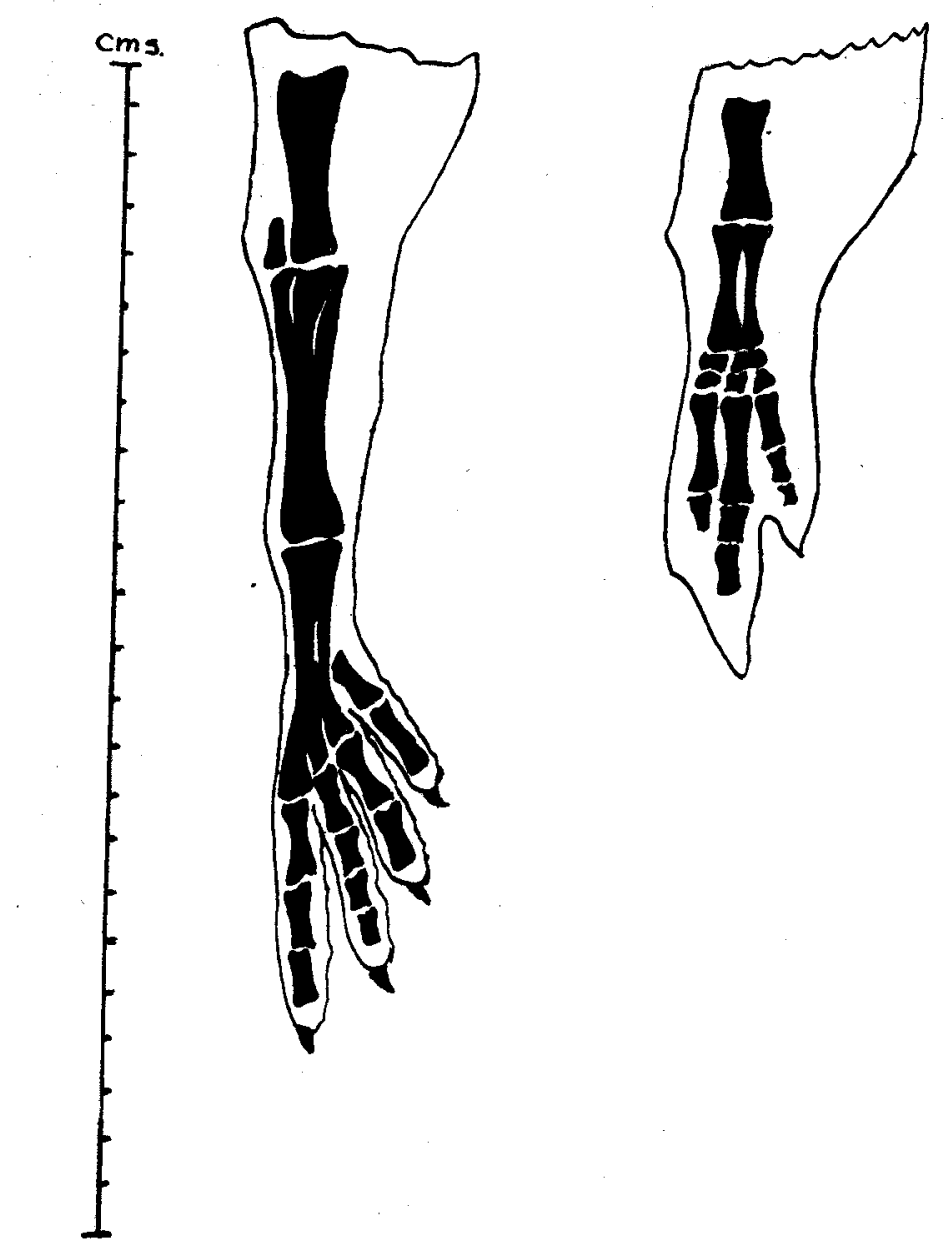

F1gure 4.

Diagrammatic drawing of a typical extended leg and wing of a 20 day old chick embryo, after treated by the potaoh method. The bones of botin leg and wing are actual oize and drawn to acale in centimeters. 
Tifference in Growth of the Long Bones

Comparizon of the bones of the experimental embryos with those of their controls brought to light marked differences.

The average length of the bones of the experimentals was one-fifth shorter and of less diameter than their control embryos. The bones of several of the experimentais were at least one-fourth shorter than their controls, as shown in Figure 3; TableI. In most cases the bodies of the experimental embryos were small and emaciated.

In only two cases E87 and E95, were these modifications apparently absent; that 1s, the growth of these two experimental animals was similar to their controls. As seen In Table I, the length of the legs of E87 and E95 were $8.9 \mathrm{cms}$. and $9.0 \mathrm{cms}$. respectively, and their control's legs measured $0.0 \mathrm{cms}$, and $0.1 \mathrm{cms}$. respectively. Winglength of these two experimentals measured $4.0 \mathrm{cms}$. and $4.0 \mathrm{cms}$. In comparison to $4.9 \mathrm{cms}$, and $3.9 \mathrm{cms}$. for their controls.

The average length of the bones of the legs of the experimental embryos was $7.61 \mathrm{cms}$., while that of their controls averaged $9.15 \mathrm{cms}$. The wing length of the experimentals averaged $3.4 \mathrm{cms}$, and those of their controls, $4.11 \mathrm{cms}$.

The avergge length of the legs and wings of the five experimental embryos that showed typical modifications 
Table I

Size of Legs and Wings of Chick Embryos Series 1 20 Days Incubation

\begin{tabular}{|c|c|c|c|c|c|}
\hline \multicolumn{2}{|r|}{ Experimental } & & & \multicolumn{2}{|c|}{ Controls } \\
\hline & $\begin{array}{l}\text { Length of } \\
\text { Legs in } \mathrm{cms}\end{array}$ & $\begin{array}{l}\text { Length of } \\
\text { Wings in } \mathrm{cms}\end{array}$ & & $\begin{array}{l}\text { Leng th of } \\
\text { Legs in } \mathrm{cms}\end{array}$ & $\begin{array}{l}\text { Length of } \\
\text { Wings in } \mathrm{cms} \text {. }\end{array}$ \\
\hline E82 & 6.9 & 3.1 & 661 & 9.2 & 4.2 \\
\hline E84 & 7.1 & 3.3 & 665 & 9.5 & 4.3 \\
\hline E85 & 7.3 & 3.3 & 667 & 9.0 & 4.0 \\
\hline 287 & 8.9 & 4.0 & 668 & 9.0 & 4.0 \\
\hline Ego & 7.1 & 3.3 & C70 & 9.1 & 3.9 \\
\hline E92 & 7.0 & 3.2 & 671 & 9.3 & 4.2 \\
\hline E95 & 9.0 & 4.0 & c72 & 9.1 & 3.9 \\
\hline & & & C73 & 8.9 & 3.9 \\
\hline & & & $c 75$ & 9.4 & 4.1 \\
\hline & & & c76 & 9.1 & 4.0 \\
\hline & & & C79 & 9.4 & 4.2 \\
\hline & & & 680 & 8.9 & 3.9 \\
\hline $\mathrm{AV}$. & 7.61 & 3.47 & $A V$. & 9.15 & 4.11 \\
\hline
\end{tabular}


was $7.08 \mathrm{cms}$. , and $3.24 \mathrm{cms}$, , respectively. Figure 5 and 5A 1llustrate graphically the growth of both legs and wings of the experimental and control embryos.

As Table I 1ndicates, there was a range in the experimental embryos of $6.9 \mathrm{cms}$. to $9.0 \mathrm{cms}$. for leg length, while their controls varied from $8.9 \mathrm{cms}$. to $9.5 \mathrm{cms}$. The wings of the experimentals varied from $3.1 \mathrm{cms}$. to $4.0 \mathrm{cms}$. In comparison to a range of 3.9 cms. to $4.3 \mathrm{cms}$. for their control embryos. The wiath of the legs and wings of the potassiumlodide modifled embryos were less in diameter, especially the legs, and the scales on their legs were less well developed than on their controls. (Fig. 3)

\section{Experiment Series 2}

of the fifty eggs placed in the incubator, thirtytwo were fertile when candled ten days later. Ninetten experimental embryos were subjected to the treatment of potassium lodide by placing a crystal of potassium-iodide weighing not more than $0.05 \mathrm{gm}$. or less than $0.01 \mathrm{gm}$. on the eg8 shell morane near the area of the grutest vasculartt $y$; while ninucen were used as controls. only ten experimental and fifteen control embryos were al 1:ve when removed from their shells on the twentieth day of incubation.

Three experimental embryos, A37, A44, and A48 showed no marked differentiation in body development 

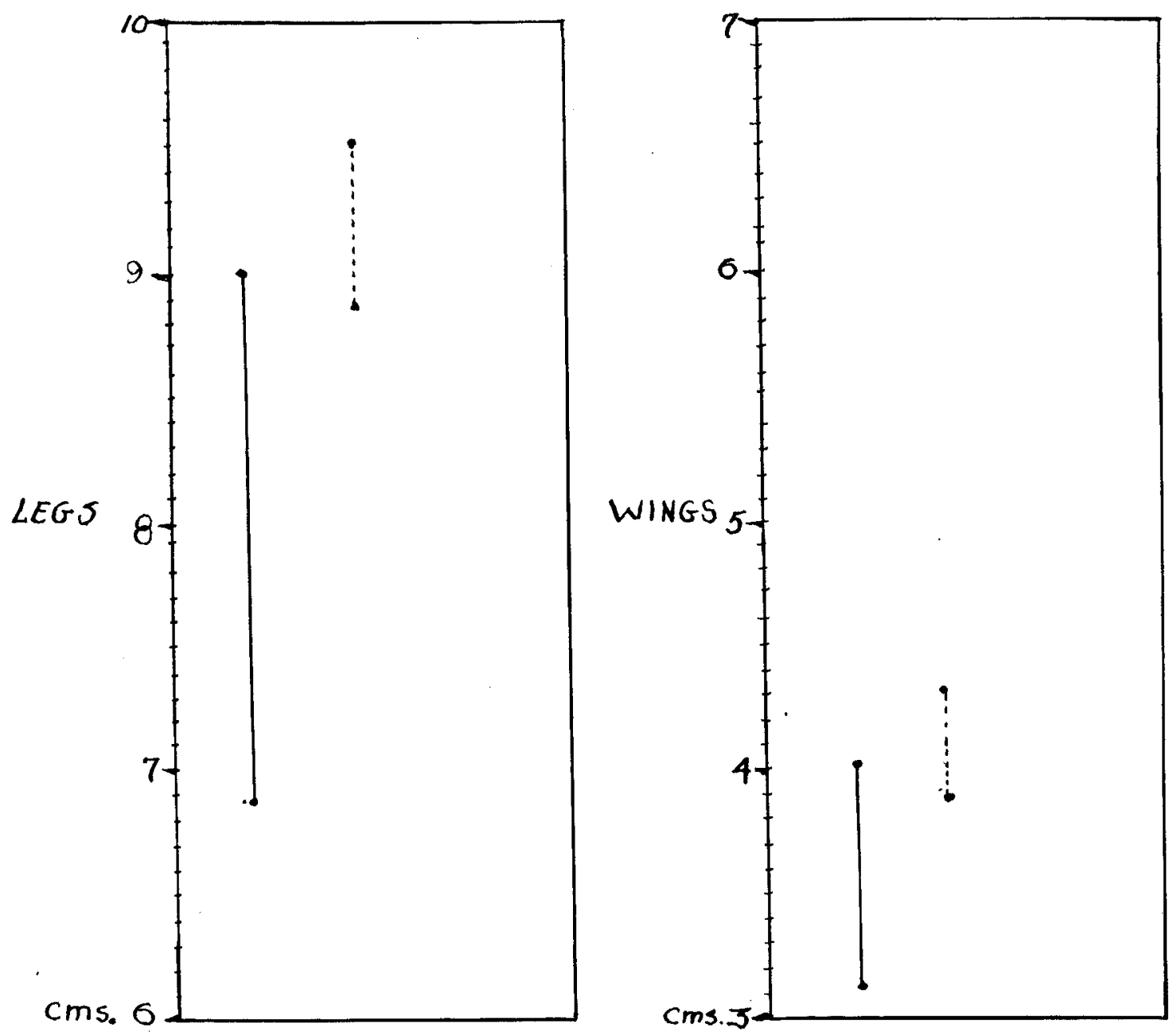

F18. 5 Graph of distribution of leg and wing-length of the twelve controls and seven experimentals chicks embryos of Series I. The broken line shows the range of the controls; the solid line, that of the experimentals. The measurements are made in centimeters. The leg-length of the experimentals range from $6.9 \mathrm{cms}$. to $9.0 \mathrm{cms}$. Those of their controls range from $8.0 \mathrm{cms}$. to $9.5 \mathrm{cms}$. The wing-length of the experimentals range from $3.1 \mathrm{cms}$. to $4.0 \mathrm{cms}$. While those of their controls range from $3.9 \mathrm{cms}$. to $4.3 \mathrm{cms}$. 

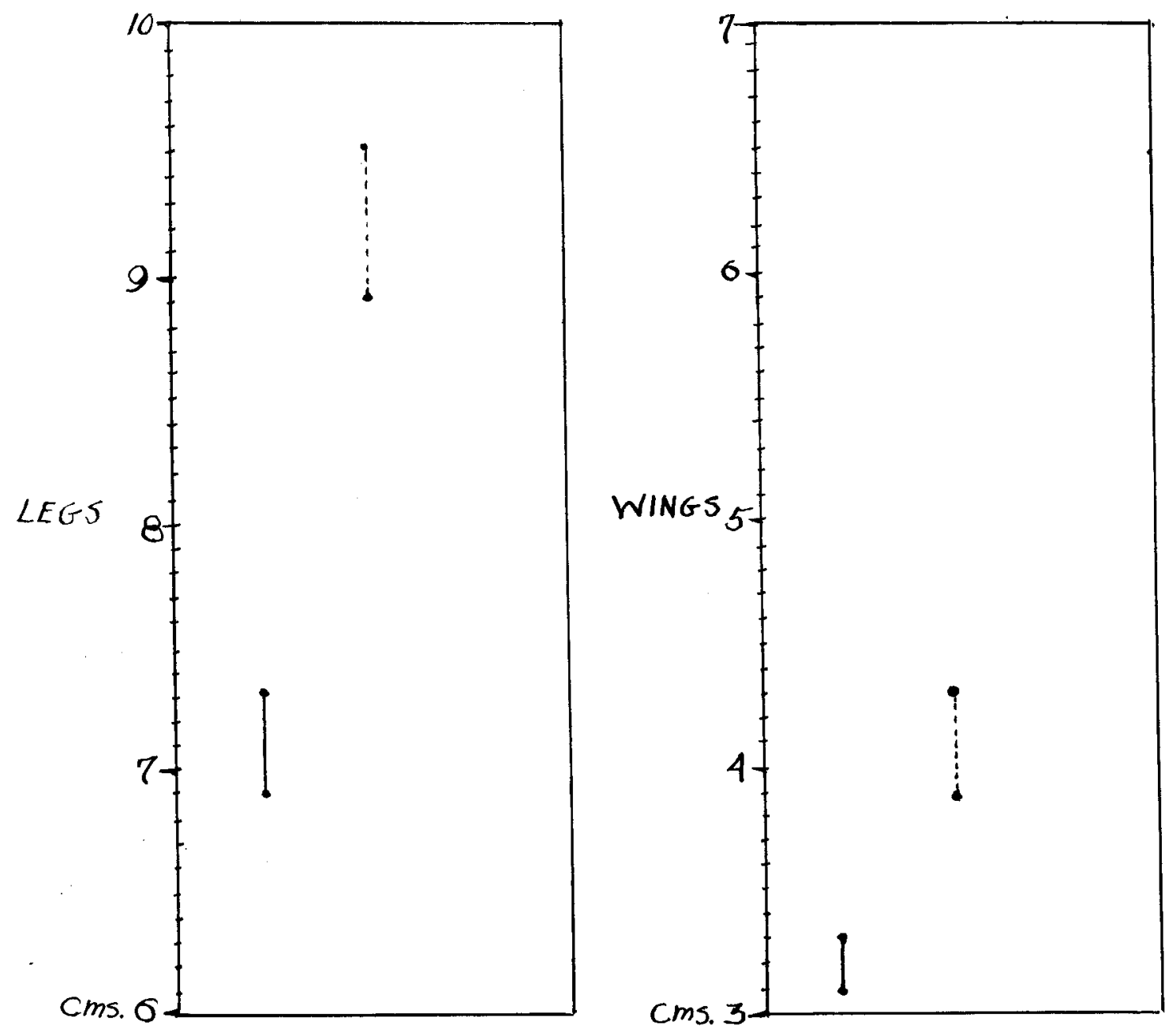

F1g. 5A Graph of aistribution of leg and wing-length of the twelve controls and 5 experinental chicks embrgos, omitting the two normal sized experimentals, Series I. The broken line shows the range of the controls; the solid line, that of the experimentals. The measurements are made in centimeters. The leg length of the experimentals range from $6.9 \mathrm{cms}$. to $7.3 \mathrm{cms}$. while those of the controls range from $8.0 \mathrm{cmg}$. to $9.5 \mathrm{cms}$. The wing-length of the experimentals range from $3.1 \mathrm{cms}$. to $3.3 \mathrm{cms}$; while those of their controls range from $3.9 \mathrm{cmg}$. to $4.3 \mathrm{cms}$. 
in comparison to their controls. Yet $A 40$ and $A 47$ were highly modified espectally effecting their legs and wings, as seen in Table II and Figure 6.

The average length of the legs of the experimentals was $8.1 \mathrm{cms}$; that of their controls $9.2 \mathrm{cms}$. The wings length of the experimentals averaged $3.6 \mathrm{cms}$. to that of $4.1 \mathrm{cns}$. for the control embryos. The legs and wings of the experimental embryos were less in diameter than their controls. In most cases the bodies of the lodide-treated embryos were small and emaciated. The average leg-length for the seven experimental embryos that showed typical modifications was $7.48 \mathrm{cms}$. and their wing-length averaged $3.35 \mathrm{cms}$. Three experimental embryos were typicaliy normal in body development. Figures 7 and $7 \mathrm{~A}$ 11lugtrate in graphic form the differences in rate of development of the experimental embryos to that of the controls.

Embryos A37, A44, and A48, al though treated w1 th potassium-iodide crystals developed normally. They showed no symptoms of modifications. Yet A40 and A47 showed marked effects, for their bodies were rather small and emaciated. Their beaks were especially small compared to those of their controls.

As seen in Table II and Figure 6 the length of the legs of $A 4 \cap$ and $A 47$ were $6.9 \mathrm{cms}$, and $6.8 \mathrm{cms}$, respectively, compared to $8.9 \mathrm{cms}$. and $9.4 \mathrm{cms}$. for their 
Table II

Size of Legs and Wings of Chick Embryos Series 2 20 Days Incubation

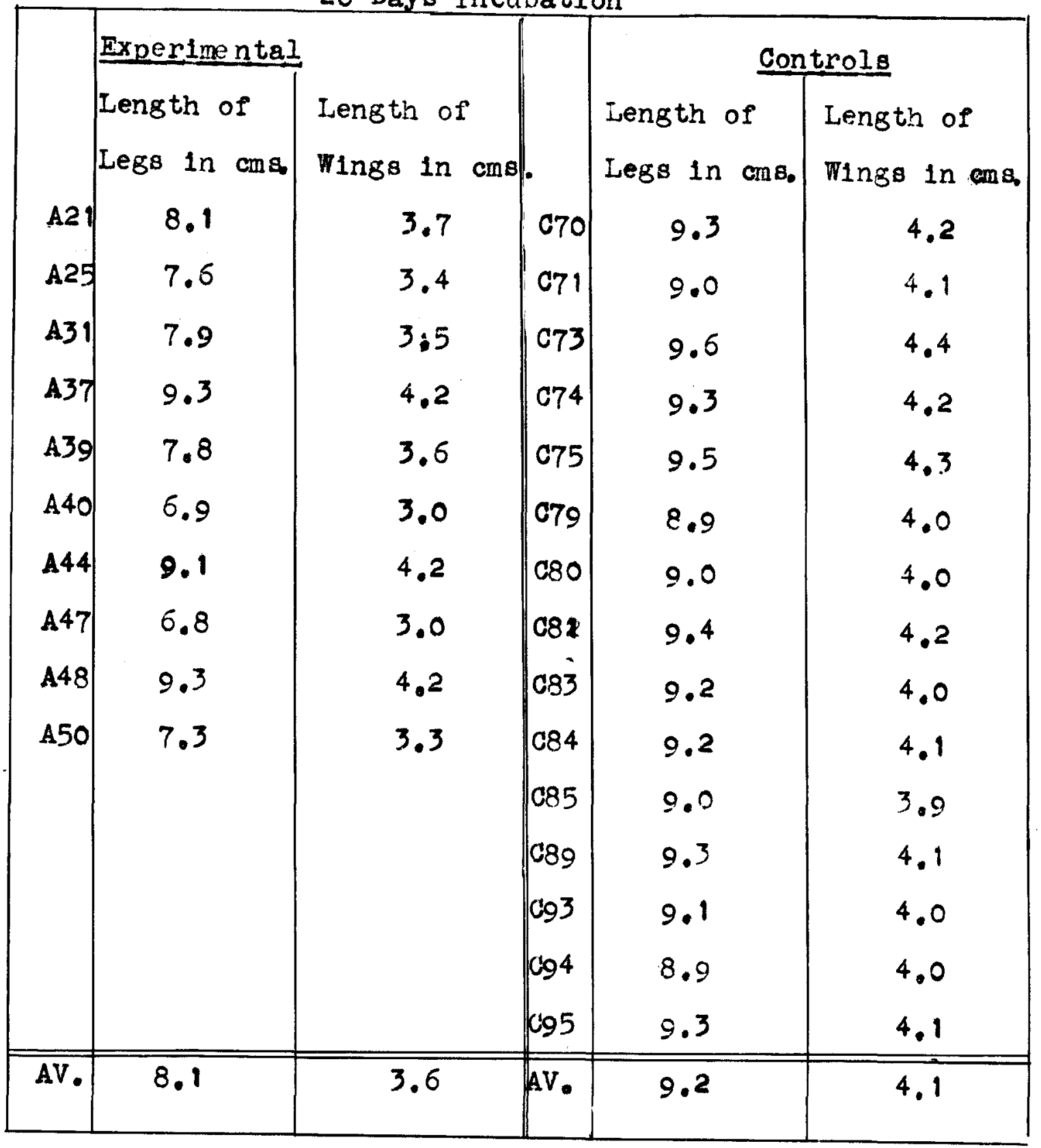




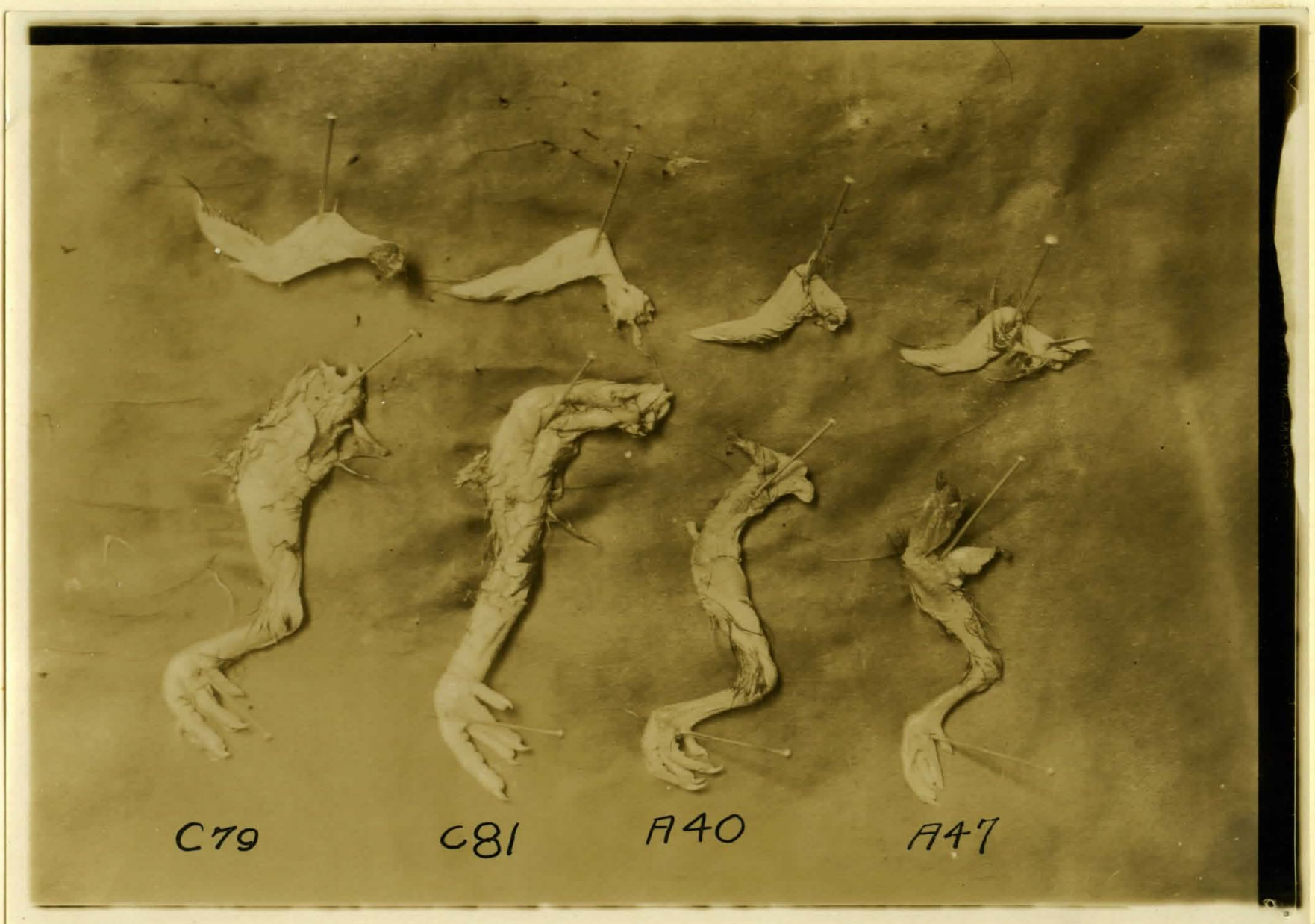

Fig.6. Comparison of KI-modified chick embryos, $A 40$ and $\mathrm{A47}$ with their respective controls, $\mathrm{C} 79$ and $\mathrm{C} 81$. 

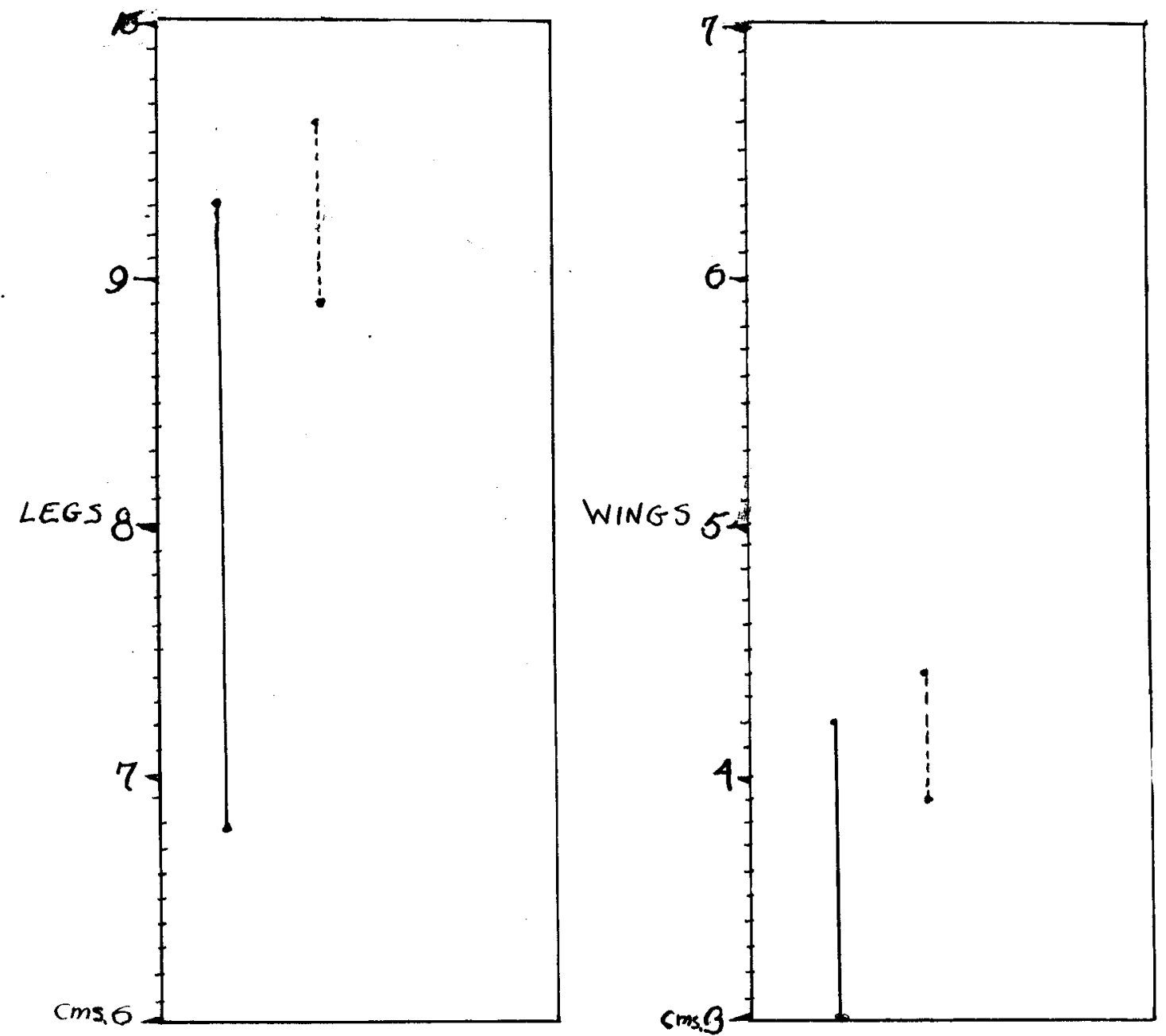

Fig. 7 Graph of distribution of leg and wing-length of 15 controls and 10 experimental chick embryos of Series II. The broken line shows the range of the controls; the solid line, that of the experimentals. The measurements are made in centimeters. The leg-length of the experimentals range from $6.8 \mathrm{cms}$. to $9.3 \mathrm{cms}$. The wing-length of the experImentals range from $3.0 \mathrm{cms}$, to $4.2 \mathrm{cms}$. while those of the controls range from $3.9 \mathrm{cms}$. to $4.4 \mathrm{cms}$. 

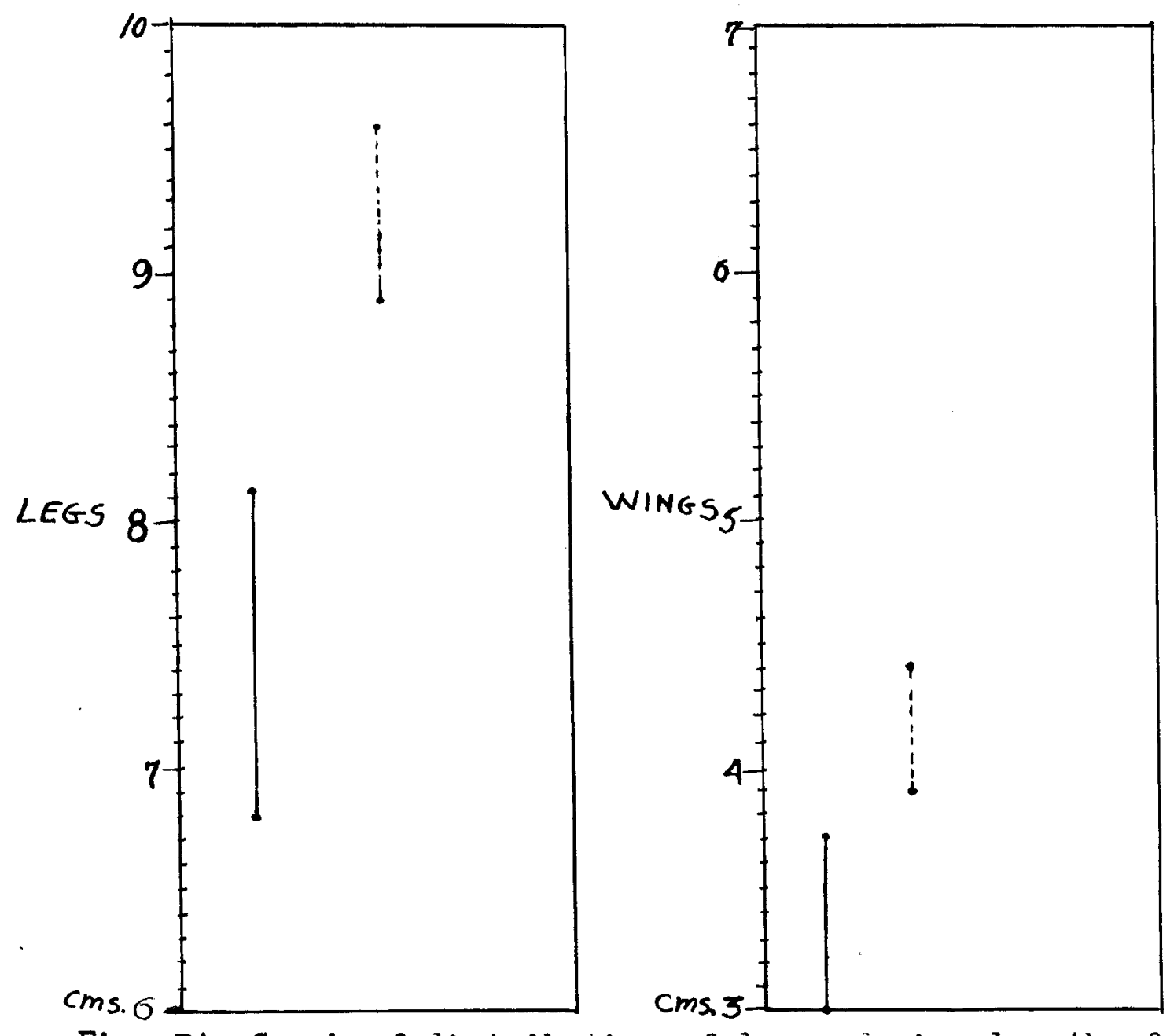

Fig. 7A Graph of distribution of leg and wing-length of 15 control and 7 experimental chlck embryos omitting 3 normal sized experimentals of Series II. The broken line indicates the range of the controls; the solld line that of the experimentala. The measurementa are made in cent1meters. The leg-length of the experimentals range from $6.8 \mathrm{cms}$. to $8.1 \mathrm{cms} .$, while those of their controls range from $8.9 \mathrm{cms}$. to $9.6 \mathrm{cms}$. The ving-length of the experimentals range from $3.0 \mathrm{cms}$. to $3.7 \mathrm{cms}$. while those of their controls range from $3.0 \mathrm{cms}$. to $4.4 \mathrm{cms}$. 
respective control embryos. The wing length was 3.0 cms. for the experimentals in comparison to $4.0 \mathrm{cms}$ and $4.2 \mathrm{cms}$. for their respective controls.

In the experimental embryos a variation in the development of the legs ranged from $6.8 \mathrm{cms}$. to 9.3 cms., and for their controls $8.9 \mathrm{cms}$. to $9.5 \mathrm{cms}$. The wing lengti in the experimental embryos varied from $3.0 \mathrm{cms}$. to $4.2 \mathrm{cms}$. while the control wing length varied from $3.9 \mathrm{cms}$. to $4.3 \mathrm{cms}$.

\section{Experiment Series 3}

In this series the experimental procedure was carried out as in series 2 The potassium-iodide crystals produced marked effects of the experimental embryos of this sertes. The slight difference in the size of the legs and wings compared to series 1 and 2 1s due to a difference of one day less of incubation. This study is based upon nine experimental and thirteen control embryos that survived from thirtyeight eggs.

An abnormal development occurred in one case, A124 was enclosed within the yolk when removed from its shell. The embryo, however, was alive.

A review of Table III shows a variation of leg length in the experimental embryos ranging from 6.9 cms. to $8.8 \mathrm{cms}$. while those of their controls vary from $8.2 \mathrm{cms}$, to $8.8 \mathrm{cms}$. The length of the wings of 
Table III

Size of Legs and Wings of Ch1 ck Embryos Series 1 19 Days Incubation

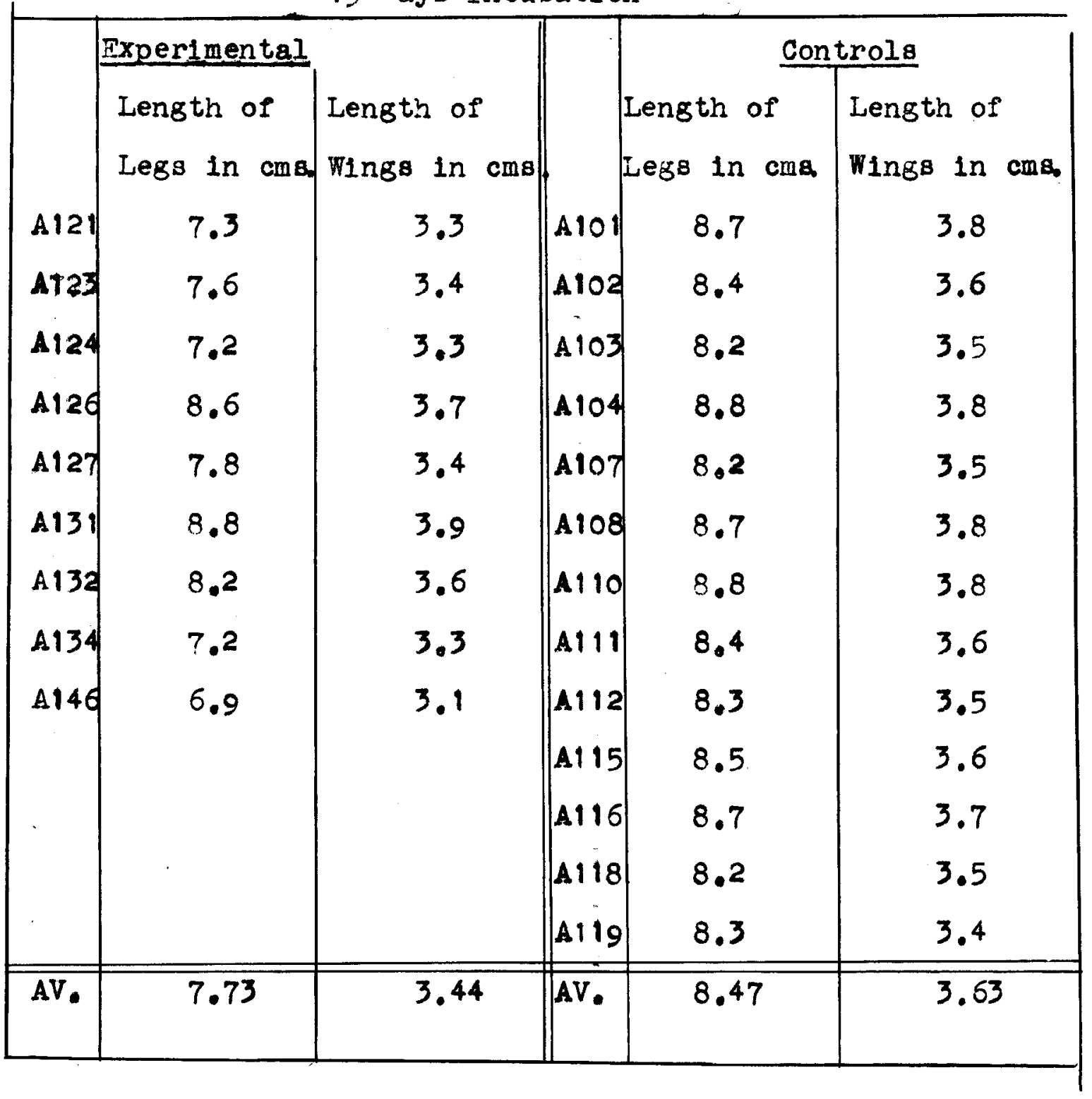


the experimentals vary from $3.1 \mathrm{cms}$ to $3.9 \mathrm{cms}$. and those of their controls range from between $3.4 \mathrm{cms}$. to $3.8 \mathrm{cms}$.

The average length of the logs of the experimental embryos were $7.77 \mathrm{cms}$. contrasted to $8.47 \mathrm{cms}$. for the leg-length of their controls, and an average wing-length of $3.44 \mathrm{cms}$. for the experimentals to $3.63 \mathrm{cms}$. for those of their controls.

Al46 showed modiflcations which were quite pronounced. Its leg-length was $5.9 \mathrm{cms}$. as compared with an average leg-length of $7.75 \mathrm{cms}$. for the entire experimental group, and an average leg-length of 8.47 cms. For the entire control group. Further, the shortest leg-length for any control embryo was 8.2 cms. The body was emaclated, the legs and wings less in diameter and the head smaller than the average for the controls. (See Fig. 8 and Table III).

However, A126 and A131 showed no signs of retarded growth. Their legs measured $8.6 \mathrm{cms}$, and $8.8 \mathrm{cms}$. in length compared to $8.8 \mathrm{cms}$. and $8.7 \mathrm{cms}$. respectively for those of their controls. The wing length measured $3.7 \mathrm{cms}$. and $3.9 \mathrm{cms}$. respectively, while the wing length of their control embryoo measured $3.8 \mathrm{cms}$. and $3.8 \mathrm{cms}$. respectively. Their les and wing length was greater 1 th regpect to the avergae les and wing length of the experimentals, yet it is almost equal to the average leg and wing lengths of the control embryos. 


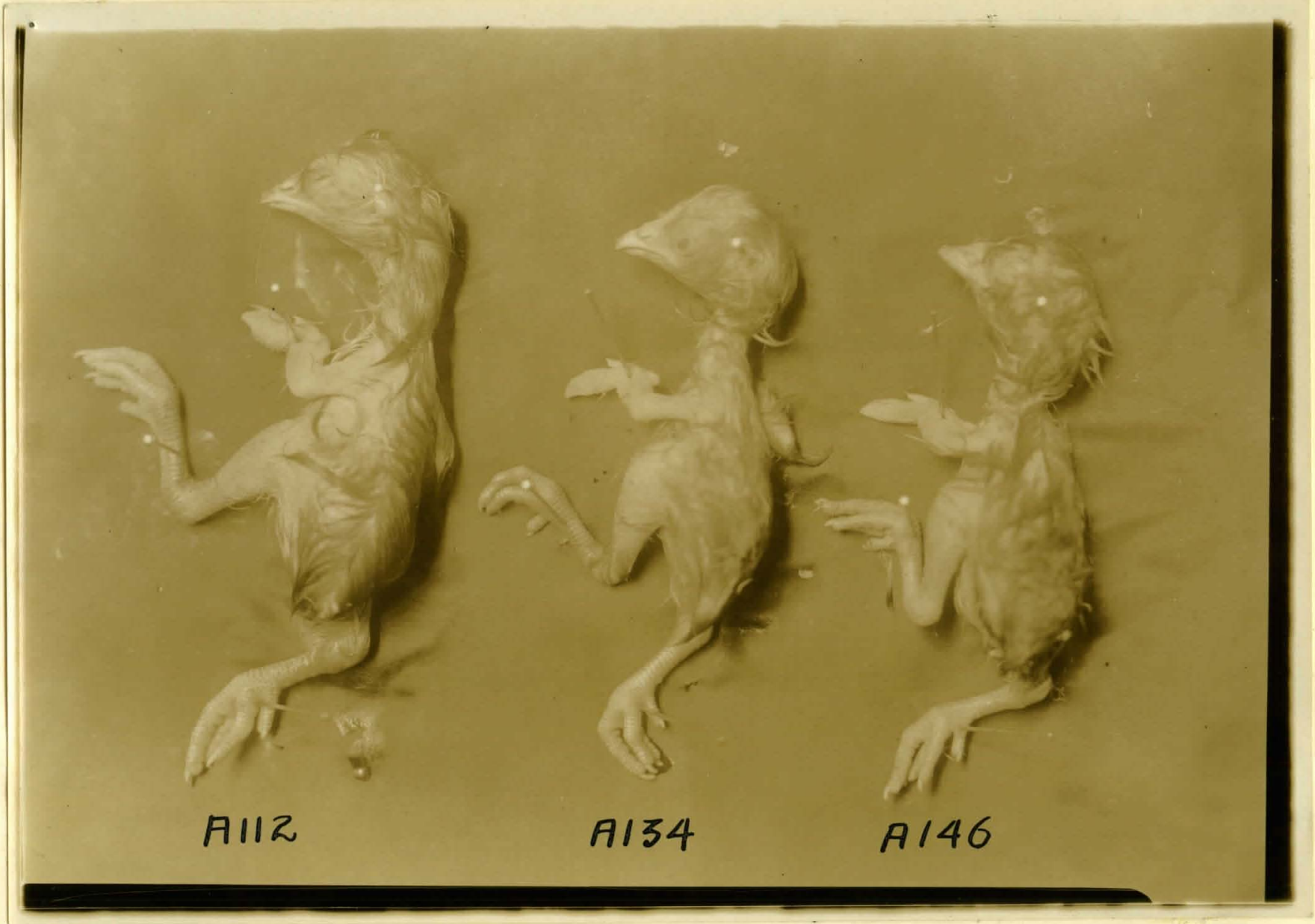

Fig.8. Comparison of KI-modified chick embryos. Al34 and Al46 with a control embryo,All2. All2 embryo is the control embryo for embryo A146 
The average leg and wing lengths for the seven experimental embryos showing typical body and long bone modifications were $7.45 \mathrm{cms}$. and $3.33 \mathrm{cms}$. respectively. Fig. 9 illustrates in graphic from the leg and wing length of the experimental embryos with those of their controls.

\section{Experiment Series 4}

The purpose of this experiment vas to study the effect of the potassium-iodide on the histological structure of the thyroid gland and compare the histological changes in these thyroid glands with those of the experimental and control chick embryos of the preceeding series. No attempt was made to measure the legs or wings of these chicks.

The thyrold gland were removed from the experimental chicks fed dally for thirteen days with one cubic centimeter of a one per cent. solution of potassium-iodide and prepared for histological study. The same was done with the thyrold $\varepsilon$ ? nds of their controls.

However, a physiological difference was hoticed between the experimentals and their control chlcks. The controls, although living under the same laboratory condilions, developed leg weakness, and before the thirteenth day, four didd. All the ex- 

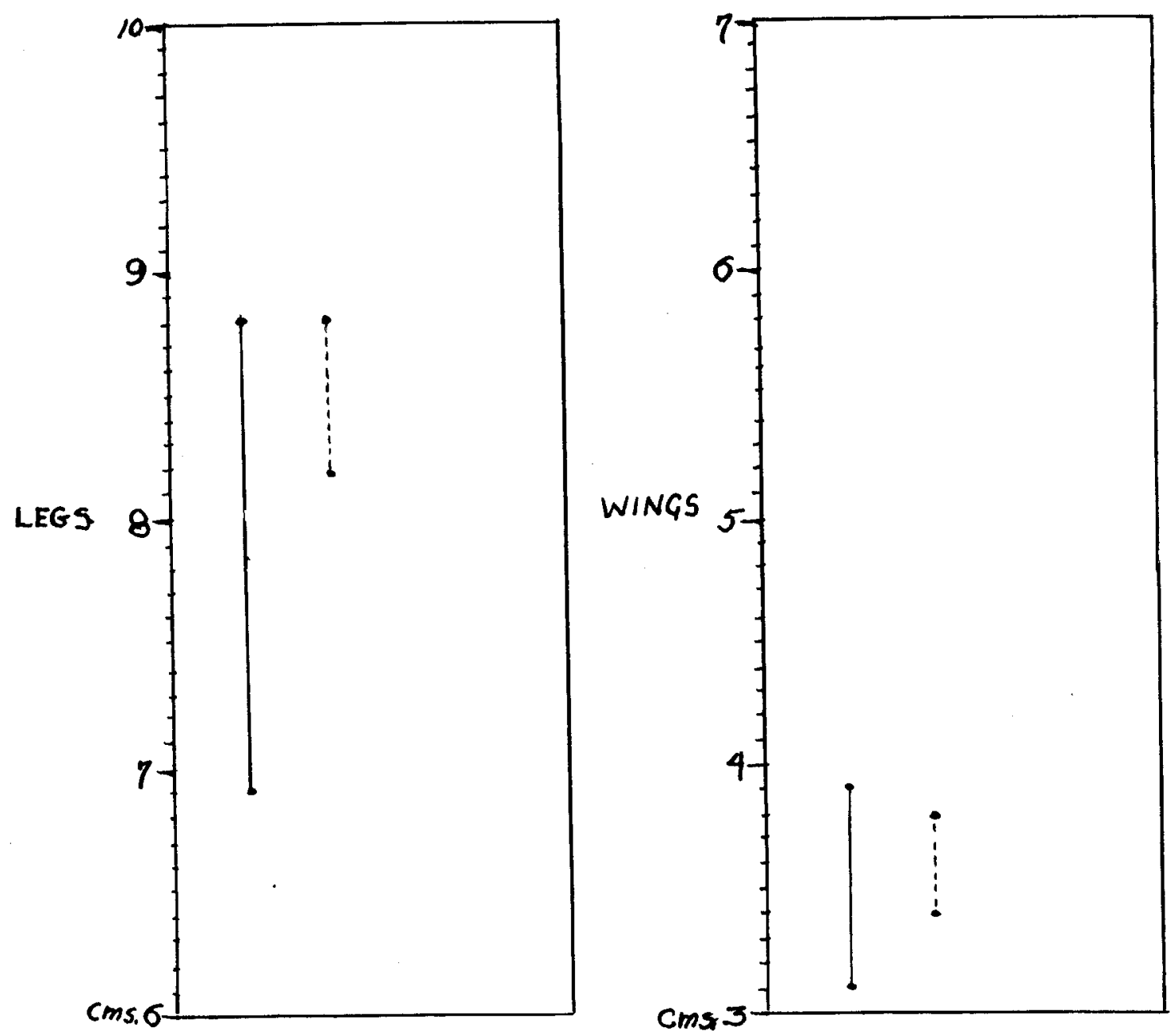

Fig. G Graph of distribution of les and wing-length of 13 control and 9 experimental chicks embryos of Series III. The broken line shows the range of the controls; the solid line, that of the experimentals. The measurements are made in centimeters. The leg-length of the experimentals range from $6.9 \mathrm{cms}$. to $8.9 \mathrm{cms}$. While those of their controls range from $8.2 \mathrm{cms}$. to $8.8 \mathrm{cms}$. The wing-length of the experimentals range from $3.1 \mathrm{cms}$. to $3.9 \mathrm{cms}$., while those of their controls range from $3.4 \mathrm{cms}$. to $3.8 \mathrm{cms}$. 

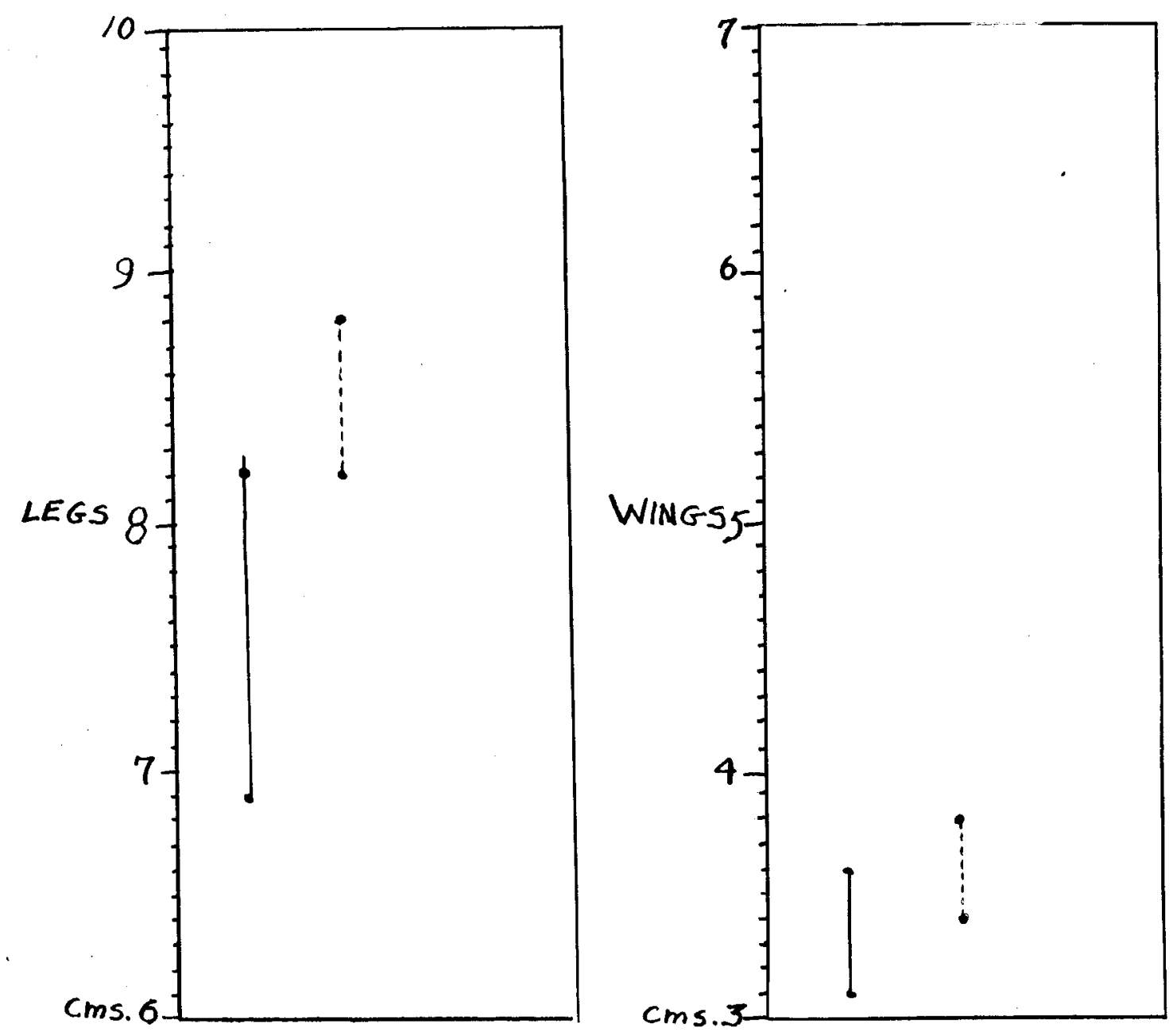

F1g. OA Graph of distribution of leg and wing-length of 13 controls and 7 cxperimentals chick embryos of series III, omitting 2 normal sized experimental embryos. The broken line shows the range of the controls; the solid line, that of the experimentals. The measurements are made in centimeters. The leg-length of the experimentals range from $6.9 \mathrm{cms}$. to $8.2 \mathrm{cms}$, while those of their controls ranse from $8.2 \mathrm{cms}$. to $8.8 \mathrm{cms}$. Th wing-iensth of the experimentals range from $3.1 \mathrm{cms}$. to $3.5 \mathrm{cms}$. While those of their controls range from $3.4 \mathrm{cms}$. to $3.8 \mathrm{cms}$. 
perimental chicks survived the potassium lodide treatment and appeared healthy.

Histology of the Thyroid Giands Embryos

$$
\text { Series 1, 2, } 3 \text {. }
$$

The thyrold glands were fixed in Bouin's fixative solution, stained in Daelafield haemotoxylin and counter-stained $w i$ th eosin. They were cut $81 x$ microns in thickness. (Fis. 10)

\section{Experimentals}

In the thyroid of the experimental embryos, the follicles were found to be chiefly oval or rounded in outline. The cells of the follieular eplthelium were approximately low columnar in form, however, many of these cells were cuboldal. The intercellular boundarles were not very definite and distinct. The cells presented a fairly uniform appearance.

The nuclei of the follicular cells were mostly sphertcal, yet many were ovolial in form. The nuclear membrane was fairly distinct and the entire nucleus deeply stalned. The collold appeared typical in form, though somewhat variable in staining. In some cases It filled the entire follicular cavity, in other cases It was retracted somewhat from the follicular epithelium.

Many vacuoles appeared in the colloid, especially near the superficial portion of the gland. These 


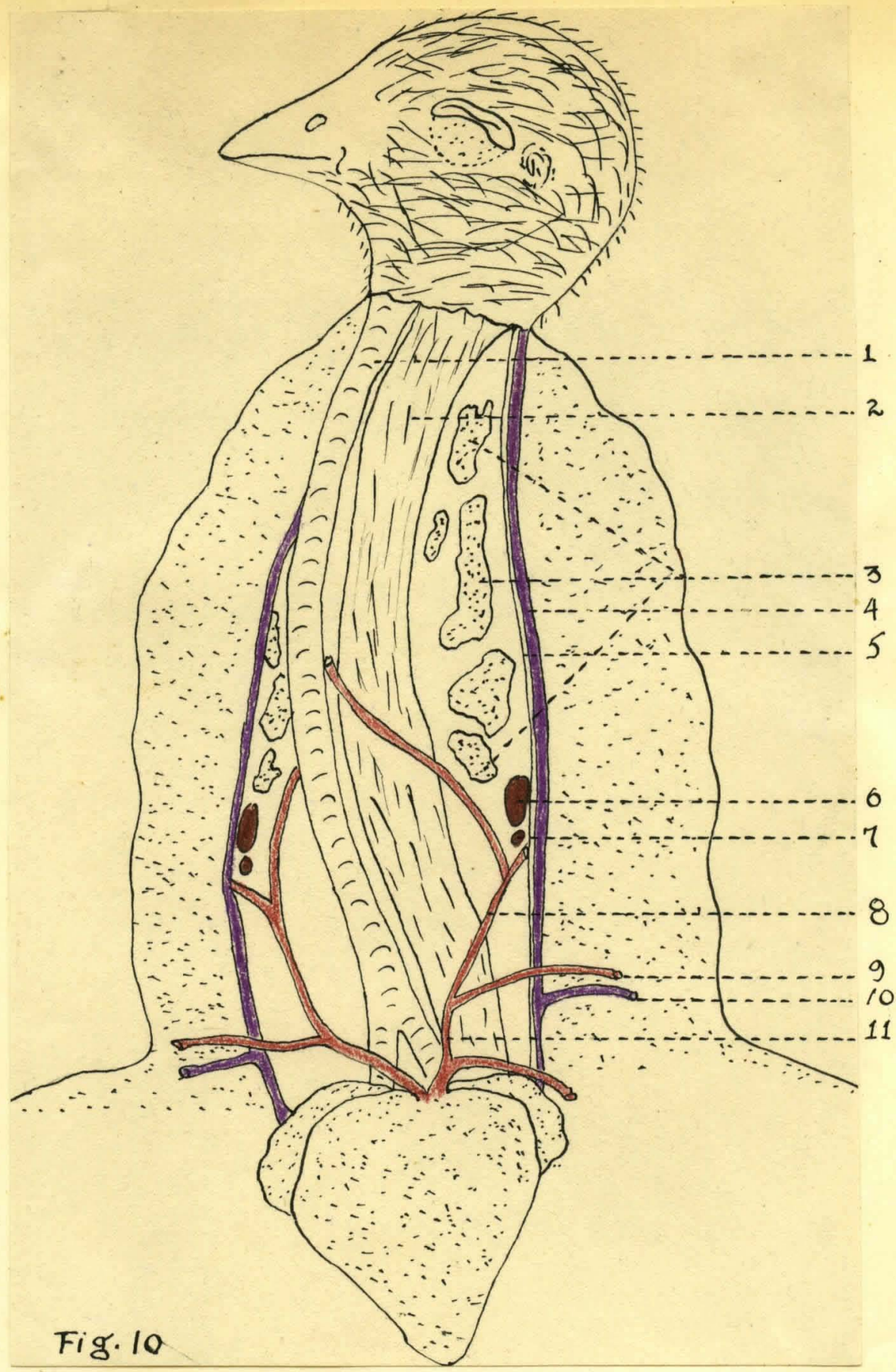

Dissected neck of a 20 day chick embryo showing the position of the thyroid and parathyroid glands.

1. Trachea; 2.oesophagus; 3.left thyrmus; 4.jugular vein; 5.vagus nerve; 6 . thyroid(left lobe); 7 .parathyroid gland(left lobe); 8.common carotid artery; 9.brachial artery; 10.brachial vein; 11. subclavian artery. 
vacuoles were usually small, however, in some follicles they replaced at least one-half of the colloid material, as seen in Figure 11. They were also spherical in form and were most frequently found near the outer edge of the collo1d, in close proximity to the follicular cells.

The interfollicular connective tissue formed a delicate fibrous stroma, typical of a nomal gland. Histologically, all the glands presented a normal picture, save for the variation in amount of the collold and the vacuolation cited above. The valiation in the amount of colloid present in the experimental thyroids and their excessive vacuolation are in no way characteristic of the normal thyroid gland.

No collold droplets, described by Bensley('14)'17 were detected in the epithelial cells of the hyperactive thyroid glands of the experimental embryos.

\section{Controls}

The thyrold glands of the control embryos studied were typically normal. The only outstanding difference between them and the experimentals was the excessive number of vacuoles found in the experimental thyroid glands. Although there were some vacuoles present in the normal glands of the controls, they were mody small in size and very few in number. 


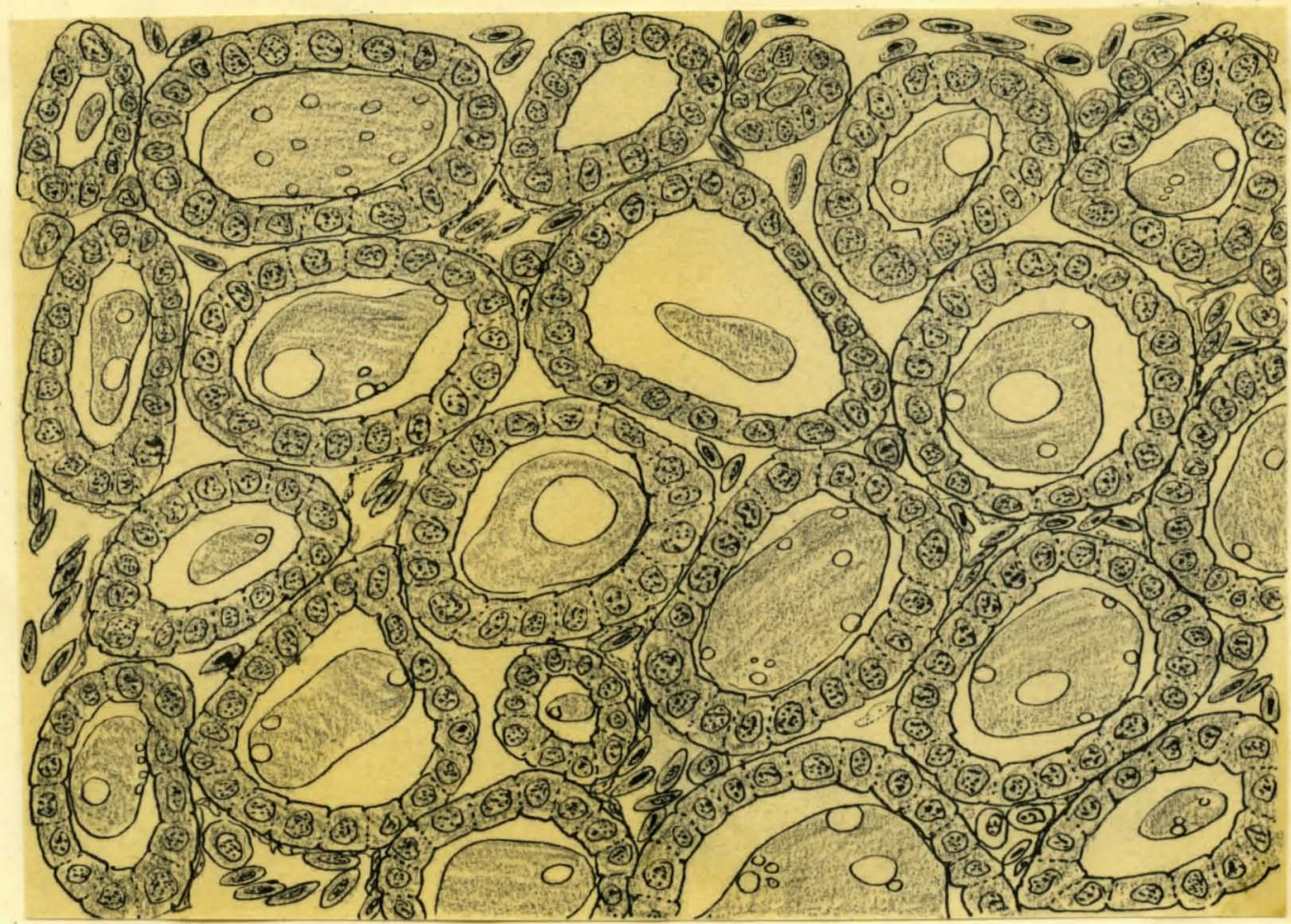

\section{F1g. 11.}

Camera-lucida drawing of the superficial portion of the thyroid gland of experimental chick embryo A40, Series 2 showing the abnormal amount of vacuoles in the colloid material. Drawn with a Leitz microscope, $x 475$. 
The follicular cells of the control thylolds were mostly low columnar. Very few of the cubcialal type of cells could be noticed. Howeves, the follieles were smaller in olze as compared with the experimentals. See Figure 12.

Histology of the Thyroid Glands of the

$$
\text { Adult chicks Series } 4
$$

The thyroid glands removed from the six, nineteen day old chicks, dosed with one cublc centimeter of a one per cent. potassium-iodide solution dally for thirteen days, were prepared for histological study and compared with the thyrolds removed from their controls and those of the experimental and control chick embryos from the three preceeding series.

The follicles in the thyroids of the experimental nineteen day old chicks were oval or rounded in outline presenting a normal appearance. The ello of the follicular eplthelium were low columnar in form with very few colloidal cells present. The intercellular boundaries were indefinite, yet the cells presented a uniform appesance.

The nuclei of the follicular cells were either opherical or ovoldal in form depending upon the shape of 1ts cells. They took the normal amount of staining w1 th respect to the surrounding structures. The 


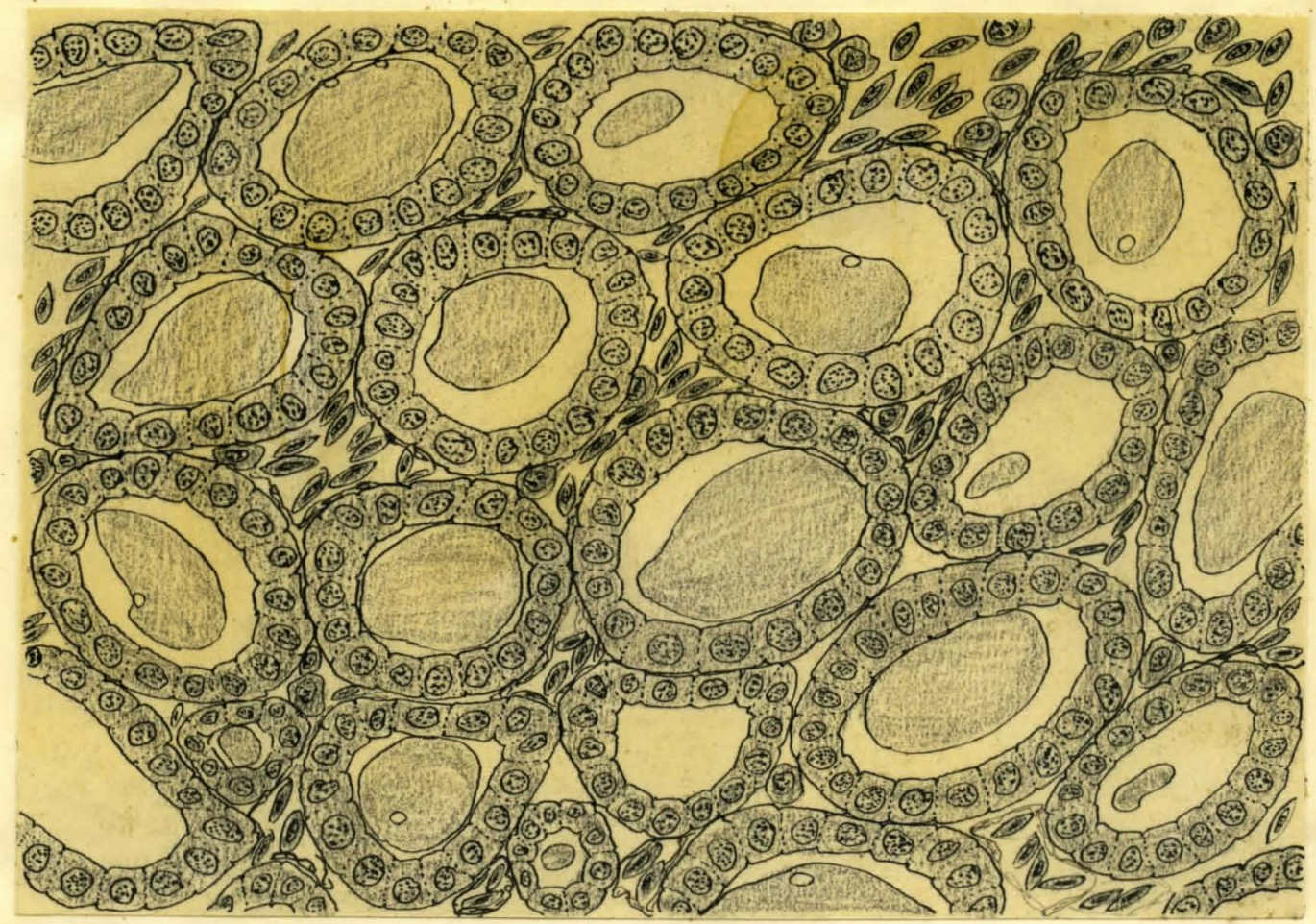

F1g. 12 .

Camera-lucida drawing of a portion of the thyrold gland of control chick embryo C71, Series I; showing the normal structure of the colloid material. Drawn with a Leitz microscope, $x 475$. 
follicular colloid atalned faintly, and filled, in some follicles the entire follicular cavity, and was elther retracted or lacking in the other follicles. The glinds showed no striking differences from those or the controls except for the number of vacuoles present in the colloid material. These vacuoles were found throughout the gland, and varied in size and number in the different follicles. They were present in different places in the colloid material, either in the center or near their edges. The size of the follicles wes slightly larger in most cases with respect to those of their controls.

Although the collotd of the thyrold glands of the experimental and control nineteen day old chicks showed typical staining properties, there was a noticeable difference in the desree of staining compared $w$ th the glands of the experimental and control chlck enbryos in the preceeding three serles. The collold of the glands of the nineteen day old chicks stained very faintly with the Delafield haemotoxylin and eosin, used in the former experiment. 
DISCUSSION 
The results presented in this paper show that potassium-iodide, when infected as a solution or in crystalline form on the egg shell membrane of the chick embryo at the eleventh day of incubation, produces body modifications that are noticeable on the nineteenth and twentieth $d z_{*}$ of incubation.

of the twe ty-six experimental chick embryos subjected to the above treatment, nineteen shored a betarded body development. In some cases their bodies were small and emaciated, and their heads and beaks were usually smaller than those of their controls. In all ninetien experimentals, the legs and wings were at least twenty-five per cent. shorter than the corregponding lengths of their controls and both types of appendages were less in diameter than those of their controls.

These effects have been generally interpreted to mean that a hyperthyrold condition has occurred, that is, that there was an increased rate of metabolism. The small emaciated bodies and the short legs and wings seem to indicate that catabolism has increased over antaolism.

This view has been supported by many recent investigators, who have studied the effect of body development in relation to the administration of lodine or some lodine containing compound to animals 
and human beings. In feeding the thyroid material in different forms to young animals, Cameron and Carmichael ('20) have shown that there is a marked diminution in size of the organs in the bodies of the animals, and the muscles of the body were of distinctly smaller size than normal. These findings suggested to them a atatus of hyperthyroidifm. The results were explained as an abnormal tissue catabolism. Although many of the organs were affected, the thyroid gland remeined normal, and was in a resting condition because of the absence of stimulation to the gland. willier(124) 16 noticed that the legs and wings of the thyroid-grafted chick embryos was smaller in ize when compared to those of their controls. He also attributed these modifications to a hyperthyroid condition.

Hammett('27), Swingle('19), Lenhart('15)? Speidel('29) $)^{13}$, Etxin $(130)^{10}$, and Allen $(' 18)^{4}$ in their work on the thyroid glands of the amplibian larvae, noticed that the thyroid gland plays a major role in the development of the body. Swingle('19) 8 otimm ulated metamorphosis in the larvae of Rana pipiens by feeding potassium-1odide, while Lenhart('15)7 found that the nigher the lodine contenc of the gland fed to frog larvae, the more rapid the body metaboliam. Such rapid body metabolism expresses itself in amphibla 
by increased rate of metamorphosia.

Hanan ('28) '14, by the introduction of thyroxin in small quantities on the alr sac of the chick embryos on the elghth day of incubation, increased the carbon dioxide production. Hering('17) 29 fed thyrold material to young white rats and found that it tended to diminish body weight, which he also attributed to an increase in rate of metabolism.

In the experimental animals there was a wide variation in the length of the wings and also in the length of the legs, as can be noted in Tables I, II, and III; Figures 4,5, and 6. Even in the controls there was a slight variation in the length of the legs and wings. Since the same amount of lodide was ured in each series one might expect to obtain the same amount of variation in each case. Towever, w11lier('21)16 reported similar variations in his experiments on chick embryos. He attributedthis to the possibility that the chlck embryos themselves varied in their physiological traits, such as rate of body metabolism and degree of registance to foreign material. This accounts for the greater degree of variation in the experinentals, since their normal physiological balance was disturbed. And it also accounts for the higher rate of mortality among the experimental embryos. 
Since hyperthyrold conditions in the chick embryos were induced by the administration of the lodide, the question arises: That role did the potassium-iodide play in the production of the modifichtions in the chick embryos? Was the lodide of potassium utilized by the thyrold gland after entering the blood stream; ur was it converted into a physiologically active substance in some of the body tisgue?

The results obtained th feeding of lodide to the thyroid-ectomized tadpoles led swingle('19)5 to advance the view that the function of the thyrold gland is chiefly for lodine storage rather than for the elaboration of specific hormones, and moreover that the tissues of his animals are capable of utilizing lodine directly without the intermediation of the gland.

The host embryos showed typlcal normal thyrold glands, according to Willier('24)', after the thyrold graft ceased to function. He believed that the thyrold graft in the chick embryo functioned independantly of the host thyroid, and in no way was it modified hiatologically by the hormone of the thyrold graft. Kendall('2g) 30 disagrees with Swingle and Willer. He belleves that the only way lodine increases metabolism in animals is through ts effect on the thyrold gland and not by 1 ts action directly on the body tissues. The relation of lodine to the physio- 
logical activity of the thyrold gland 1a very close; In fact the activity of the gland depends upon 1.ts content. Etkin('30) ${ }^{10}$ also noticed in Rana pipiens a relationship between the physiological activity of the gland and the growth of the hind limbs. However, Abelin('27) 31 showed that there is no paralleliam between biological activity and the amount of lodine. on the other hand, Rabonovitch(' 28$)^{32}$ noticed a rapid increase of proliferation of the thyroid epithelium, as evidenced by the great increase of mitoses, when guinea pigs were injected with potassium-iodide intraperitoneally. The increase was greater when large amounts of potassium-iodide was administered. Marine and Rogoff('17 $)^{33}$ produced definite histological changes in the thyroid gland of tadpoles in twenty-four hours by the injection of $50 \mathrm{mg}$. of lodine. The greater the degree of stimulation the more pronounced were the chnages in the thrrold gland.

The histological appearances of the thyrold glands of the lodide-treated chick embryos and the nineteen day old chicks were in closer sgreement with the latter investigators. It has therefore been concluded that in these experiments, the potaseium-1odde so stimulated the trijrold gland in some vey, as to buing about a hyper-active condition. The thyroid glands in many of the chlck embryos treated with potassium- 
lodide, showed no degree of change in the amount of colloid present, or in its staining properties. The findings of various investigator in regard to thyroid changes following some form of lodine treatment, either as an inorganic salt, or the gland substance 1tseje, have not been uniform.

Swingle('19), Marine and ler.wart('og)' 'Grand Bensley ('16) 17 report that in a hyper-active gland the colloid mass is increased. Aesbacher('05) ${ }^{34}$ atates that the variation in staining properties of the colloid indicates a varying lodine content. Thomas and Delhougne('24) 35 , Hewer('27) 35 , and Marine and Lenhart(' $\infty)^{19}$ report a parallelism between the lodine content and the amount of collold material. Yet Claude and Blauchetiere('10) 20 found that the iodine content and the amount of collold present in the thyroid gland is by no means a true index of the functional activity of the gland. Collold may be increased in conditions where the functional activity of the gland is diminished as in hypothyroldism. Such apparent discrepancies he interprets as being equally due to aborption, which he regards as being fully as important as secretion. He also believes that the amount of collold found in a gland depends upon secretion and absorption, and the physlological activity of the 
8land depends largely upon the equilibrium between ther. In one instance, there may be verylittle collold in an extremely active gland due to rapid absorption of the thyroid product yet on the other hand there may be much colloid in the follicles when secretion and aboorption have been diminished.

Many vacuoles were found in the colloid material of the glands of the iodide-treated embryos. (Figure 10)

These vacuoles were especially noticeable in the superficial porti on on the glands. Uhlenhuth('23) 21 .

has noticed vacuoles in hyper-active glands, while rey ('23) 22 belleves that these vacuoles serve as a histological criterion of the degree of activity of the thyrold. Wyss'('89) 38 study on the effect of pilocarpine poisoning in cats and rabbits, revealed vacuoles in the acini of the follicles, which he attributed to an engorgment of the thyrold gland with blood. Because of the1r lack of affinity for stains he termed these vacuoles "Chromophobe" secretions. Bensley('22) 39 described vacuoles which occurred in the base of a normal gland. He belleves that these racuoleorare the real antesedents of the secretion of the thyrold gland. He also observed (Bensley 116$)^{17}$ that the pyperplastic glands in opossums fed with lodine, appeared almost identical in histological structure with the normal thyrold gland of the controls, yet differed markedly in the amount of vacuoles, and thus probably in secretory potential, 
conflrming the former experiment of Marfne and Kendall on mammals. Even, Wen-Choa Ma $(125)^{40}$ also described the presence of vacuoles in the thyrold gland. These vacuoles almost filled the entire follicular lumen.

The thyroid glands of the modified chick embryos in these experiments show histological features that are in agreement with Bensley ('16)'? Uhlenhuth('23)', von $W y s s(' 80)^{38}$, and others, that is the presence of vacuoles in the thyrold follicles of the chlck embryos indicates that the lodide was utilized by the thyroid gland, as evidenced by the increased amount of secretion present in the form of vacuoles in question. 
SUMMARY 
1. The purpose of these experiments was to make an analyais of the effect of potassium-iodide on the embryological development of the chick, especially on the growth of the long bones (Legs and wingsl, and also of 1 ts effect upon the histological activity of the thyroid gland.

2. Potassium-iodide, as a solution or in crystaline form was placed upon the egg shell membrane of 4. chlck embryo in the region of the greatest vasm cularity. The lodide was administered on the eleventh day of incubation, and the embryos were removed from their shells on the twentieth day in Serieg $I$ and II, and on the nineteenth day in Series III.

3. Nineteen of the twenty-six experimental en bryos showed typical modifications. Their bodies were small and emaciated. Thier legs and wings were shovter than those of their controls and the diameter of their bones were recognizably shorter.

4. The leg and wing length of the experimental embryos varied from a slight modification to a retarded growth of at least twenty-five per cent. of those of their controls. 
5. The thyroid glands of the experimental chlcix embryos appeured normal, histologically, except for the excess amount of secretion-loaded vacuoles in the colloldal material near the superficial portion of the gland, which is condidered indicative of hyper-activity by many recent inveatigators.

5. The thyrold glands of six, nineteen day old chicks dosed daily with one $c, c$. of a one per cent. solution of potassium-iodide for thirteen days, we re studied and compared with those of the exrerimental chlck embryos. The glands showed histological structures that were identical with those of the experimental chick embryos.

7. The modifications in body size, retarded leg and Wing growth and the abnowal num ber of secretionloaded vacuoles in the thrrold glands, are considered to be hypertiyrold symptoms, which may be interpreted to mean that there was an increase of catabolism over anabolism. 
BIBLIOGRAPHY 
1. Baumann, E. Ueber des Normale Vorkommen von Jod Im Thierkorper Z. physiol. chem. xx1; 319 - 330. 1895 - 1806.

2. Terry, George, S. The Effects of the Extirpation of the Thyroid Gland Upon the Ossification in Rana plplens. Am. Jour. Zool. 24: 567-589. 1918.

3. Holmeister, F. Zur Frage nach den Folgezustanden der SChilddrusen-erstupilation. Deut, med Wochsehr. $x \times 11: \quad 354-355 \quad 1896$

4. Allen, B. A. Thyrold Removal in Larva of Rana pipiens. Jour. Exp. Zool. 24: 499 - 5201918.

5. Swingle, Relation of Iodine to Thyrold. The Effects of Feeding Iodine to Normal and Thyro-ectomized Tadpoles. Jour. Exp. Zool. 27: $397-4151919$.

6. Kendall, E.C. A Method for the Decomposition of the Proteins of the Thyroid, with a Description of Certain Constituents. Jour. Biol. Chem. Vol. 20: 501. 1915.

7. Lenhart, C.H. The Influence upon Tadpoles of Feeding Thyroid Gland in Variable Amounts and of Variable Iodine Content Jour. Exp. Med. xxi1 $739-746.1915$.

8. Swingle, W. W. Studies of Relation of the Iodine to the Thyrold: Comparison of the Thyroid Glands 
of Iodine-fed and Normal Fros Larvae. Jour. Exp. Zool. 27: 417 - 425. 1919

9. Dye, J. A. and Maughan, G.H. Further Study of the Thyrold Gland: The Thyrold Gland as a growth-promoting and form-determining factor in the development of the animal body. Amer. Jour. Anat. 44:

3: $331-368.1929$

10. Etkin, Wm. M. Goowth of Thyrold Gland of Rana piplens Biol. Bull. 11x: 3: $285-2921930$.

11. Caycor, H.D. and Schlotthauer, C.F. Cretinism ana Myzedema Produced Experimertially in Surne. Amer. Jour. Physiol. 1xx1x: 141-148 1927.

12. Landauer, W. Thyrogenous Dwarfism(Myxoedema infantilia) in the Domestic Fovl. Aner. Jour. Anat. 43: 1: 1-44 1929.

13. Speidel, O.K. Studies of Hyperthyroldigm Regenerative Phenomena in Thyroid-treated Amphiblan Larvae. Amer. Jour. Anat. 43: 2: 103-166 1929

14. Hanan, E.B. The Effect of Thyroxin on the Growth Rate and Carbon-dioxide Production of the Chick Enbryo. Proc. Soc. Exptl. Biol. Med. 25: 422-425 1928

15. Sheard, C. and Higgins, G.M. Influence of Irradiation by Air-cooled Quartz-mercury Arcs on the Incubation of Eggs. Jour. Exp. Zool. 57: 2: $205-2211930$. 
16. Willier, B.H. Endocrine Glands and the Development of the Chick: 1. the effects of thyroid grafts. Amer. Jour. Anat. 33: 1: 67-103. 1924.

17. Bensley, $R_{0} R$. The Influence of Diet and Iodides on the Hyperplasia of the Thyroid Gland of Opossum In Captivity. Amer. JourM Anat. 19: 57-65 1916.

18. Gray, S.H. and Rabinovitch, J. Effect of Feedine Small Doses of KI on the Thyrold Gland. Proc. Soc. exptl. B10l. Med. 26: 468-471 1929

19. Marine, $D$. and Lenhart, $C . H$. Relation of Iodine and the structure of the Thyrold Gland in the Sheep, Dog, Hog, and ox. Arch. Int. Med. 3: 66-77 1909

20. Claude, H, and Blanchetiere, A. Sur la Teneur en Iode de la Glande Thyroide Dans Ces Rapports avec la Consitution Anatomique de l'oryane. Jour. Physiol. path. gen. xif: 563 - 579 1010.

21. Uhlenhuth, E. Elaboration and Release of the Colleid of the Thyroid. Proc Soc. Exper. Biol. Med. New York 20: 494 - $496 \quad 1922$ - 1923.

22. Key; J.A. The Secretion Antecedants and Mitechondria In Pathologic Thyroid; A theory of the mode of secretion of the thyrold gland. Arch. Surg. Chicago. $254-303 . \quad 1925$. 
23. Waite, R.H. Poultry sience anc Practice $87-108 \quad 102 ?$.

24. Halbersleben, C. and Mussehl, T.W. Poultry Science I: Na4 1922

25. Danchakoff, $V$. The Position of the Resplratory Vasoular Net in the Allantiols of the Chick. Amer. Jour. Anat. 21: 407-415 1903.

26. Barthalow, R. Practical Treatise on Materid Medica and The rapeatica. 225. 1903.

27. Lee, B. The Microtomist Vade Mecum(After Mall) $482-483 \quad 1928$.

28. Hammett, F. S. Studies of the Thyrold Apparatus; The role of the thyroid and parathyroid in the growth of the long bones. Jour. Exp. Zool. xlv11. $95-1151927$.

20. Hering, P.T. The Action of the Thyroid upon the Growth of the Body and organs of the White Rate Quart. Jour. Exp. Physiol. x1: 231-253 1017.

30. Iendall, E.C. Thyroxin. 146- 1621929

31. Abelin, C. Uber den Jodgehalt van Kropfen 1m Vergleigh zu ihrer, histologischen strucktur und ihrer Wirkung im Kaulquappenversuch. Arch. Exp. Path, Mokol, cxxiv, i -40 : 1927

32. Rabinovitch, J. The Effect of Intraperitoneal Injection of $K I$ on the Proliferative Activity 
of the Thyrold Gland in Guinea Pigs. Amer. Jour. Path. 5: 191-197 1928.

33. Marine, D, and Rogoff, J.M. Fow Rapidly does the Intact Thyroid Gland Elaborate 158 Specific IodineContaining Hormone? Jour. Pharmacol. 1x: 1-10 1917. 34. Aeschbacher, S. Ueber den Einfluss krankhafter Zustande auf den Jod-und Phosphorgehalt der normalen Schildrusse. Mitt Grenzg. Med Ch1r. xv: 260-206. 1905.

35. Thomas, E. and Delhougne, E. Studien an Schildrusen von Kolner Kindern bezuglich des Jod-und Kollo1d gehaltes. Arch. Path. Anat. Phylol. ccxlvili. 201-216. 1924.

36. Hewer. EE. The Activity of the Thyrold Gland in Relation to the Staining Reactions of the Colloid Jour. Path. Batt. 30: 621-626 1927

37. Crott1, A. Thyroid and thymus $65-751918$ 38. von Tyss, $\mathrm{H}$. Veber die Bedeutung der Schildruse Cor-blf. schweiz Anrzte 20: 25 - 33 1922.

39. Bensley, R.R. The Thyroid Gland of the Opossum Anat. Record. Phil. 30. 25-33 1922.

40. Wen-Choa Ma, The Mitochondria and Collold in the Thyrold Gland on the Adult Albino Rat. Amer. Jour. Anat. 35: 2: $199-2151925$. 